WSRC-TR-2003-00352, Rev. 0

Distribution Category: Unlimited

Keywords: Tank $48 \mathrm{H}$,

Tetraphenylborate, organic

destruction, steam reforming

Retention: Permanent

TTR:HLE-TTR-2003-102

\title{
DISPOSITION OF TANK 48H ORGANICS BY FLUIDIZED BED STEAM REFORMING (FBSR) (U)
}

\author{
C. M. Jantzen
}

Publication Date: September 18, 2003

Approved by:

J.C. Griffin, Research Manager

Waste Processing Technology Section

Westinghouse Savannah River Company

Savannah River Site

Savannah River Technology Center

Aiken, SC 29808

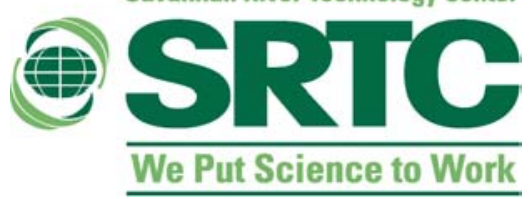

PREPARED FOR THE U.S. DEPARTMENT OF ENERGY UNDER CONTRACT NO. DE-AC09-96SR18500 
This document was prepared in conjunction with work accomplished under Contract No. DE-AC09-96SR18500 with the U. S. Department of Energy.

\section{DISCLAIMER}

This report was prepared as an account of work sponsored by an agency of the United States Government. Neither the United States Government nor any agency thereof, nor any of their employees, makes any warranty, express or implied, or assumes any legal liability or responsibility for the accuracy, completeness, or usefulness of any information, apparatus, product or process disclosed, or represents that its use would not infringe privately owned rights. Reference herein to any specific commercial product, process or service by trade name, trademark, manufacturer, or otherwise does not necessarily constitute or imply its endorsement, recommendation, or favoring by the United States Government or any agency thereof. The views and opinions of authors expressed herein do not necessarily state or reflect those of the United States Government or any agency thereof.

This report has been reproduced directly from the best available copy.

Available for sale to the public, in paper, from: U.S. Department of Commerce, National Technical Information Service, 5285 Port Royal Road, Springfield, VA 22161, phone: (800) 553-6847, fax: (703) 605-6900

email: orders@ntis.fedworld.gov

online ordering: http://www.ntis.gov/help/index.asp

Available electronically at http://www.osti.gov/bridge

Available for a processing fee to U.S. Department of Energy and its contractors, in paper, from: U.S. Department of Energy, Office of Scientific and Technical Information, P.O. Box 62, Oak Ridge, TN 37831-0062,

phone: (865)576-8401,

fax: (865)576-5728

email: $\underline{\text { reports@ adonis.osti.gov }}$ 
WSRC-TR-2003-00352, Rev. 0

WSRC-TR-2003-00352, Rev. 0

Distribution Category: Unlimited

Keywords: Tank 48H,

Tetraphenylborate, organic

destruction, steam reforming

Retention: Permanent

TTR:HLE-TTR-2003-102

\section{DISPOSITION OF TANK 48H ORGANIC SLURRY BY FLUIDIZED BED STEAM REFORMING (FBSR) (U)}

C. M. Jantzen

Publication Date: September 18, 2003

Approved by:

J.C. Griffin, Research Manager

Waste Processing Technology Section

Westinghouse Savannah River Company

Savannah River Site

Aiken, SC 29808

Savannah River Technology Center
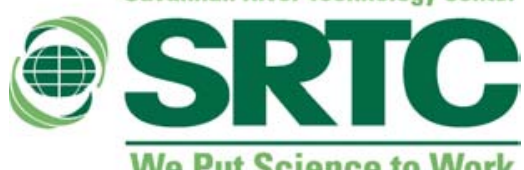

PREPARED FOR THE U.S. DEPARTMENT OF ENERGY UNDER CONTRACT NO. DE-AC09-96SR18500 
WSRC-TR-2003-00352, Rev. 0

This page intentionally left blank. 


\section{TABLE OF CONTENTS}

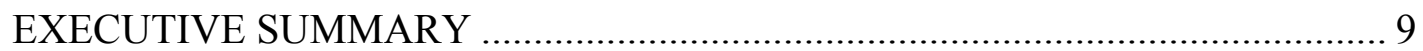

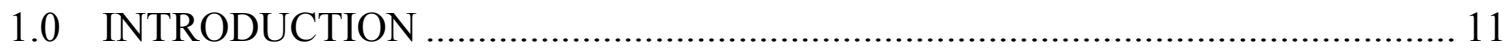

2.0 FLUIDIZED BED STEAM REFORMING (FBSR) ………................................ 13

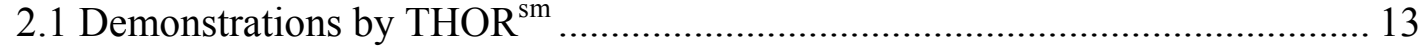

2.2 Operation and Flowsheet Options.............................................................. 15

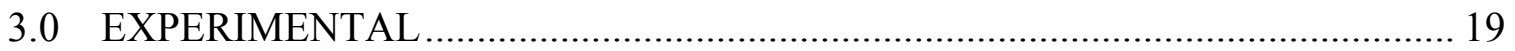

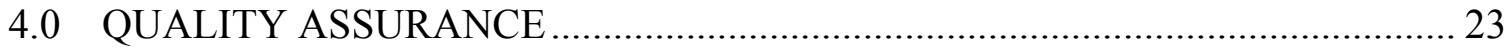

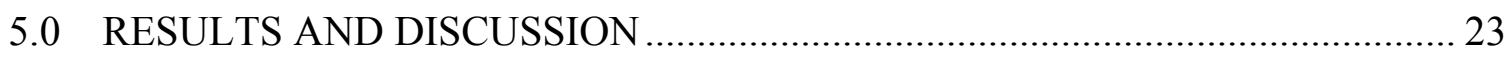

5.1 Static Vs. Dynamic Tests and Reaction Residence Time .................................. 23

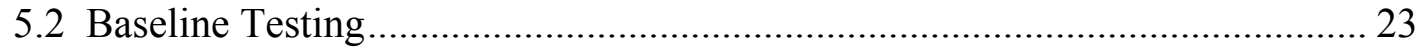

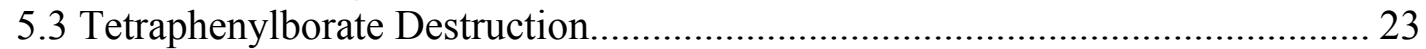

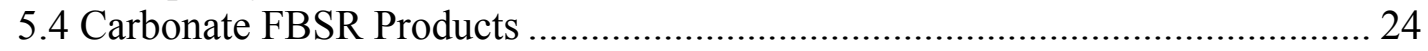

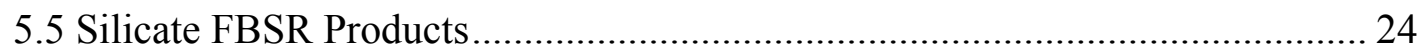

5.6 Nitrate and Sugar Destruction................................................................. 25

5.7 Particle Agglomeration ............................................................................... 26

5.8 FBSR Product Melt Temperatures............................................................... 26

5.9 REDOX Measurements and the Water Gas Shift Reaction (WGSR)............... 28

5.10 Volumes of FBSR Product For DWPF ........................................................ 30

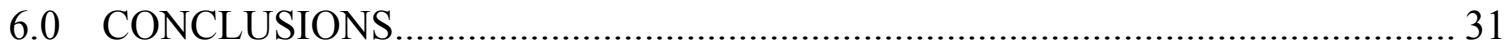

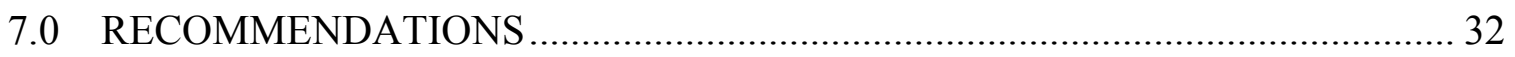

APPENDIX A ……………………………………………………………………………ㄴ... 


\section{WSRC-TR-2003-00352, Rev. 0}

\section{LIST OF FIGURES}

Figure 1 Typical FBSR flowsheet proposed by THOR for DOE Tank wastes...................16

Figure 2. Tank $48 \mathrm{H}$ simulated slurry during (left) and after (right) carbonation. Note foaming in sample before and during carbonation. ..........................................21

Figure 3. Schreiber's relationship between imposed oxygen fugacity $\left(-\log f\left(\mathrm{O}_{2}\right)\right)$ and the REDOX ratio $(\log ([$ reduced ion $] /[$ oxidized ion $]))$ for multivalent elements

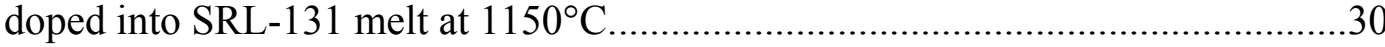




\section{WSRC-TR-2003-00352, Rev. 0}

\section{LIST OF TABLES}

Table 1. $\quad$ THOR $^{\text {sm }}$ Pilot Scale Demonstrations Performed at Hazen Research ...................14

Table 2. Discharges and Emissions from a Production-Scale THOR ${ }^{\mathrm{sm}}$............................18

Table 3. Tank 48H Simulant Recipe........................................................................ 19

Table 4. Simulated T48H Steam Reformer Optimization Matrix, X-Ray Diffraction Analysis, HPLC Analysis, and Nitrate Destruction...........................................22

Table 5. Analysis of Anions and Cations in Tank 48H Simulated FBSR Products ...........27

Table 6. Measured REDOX, Total Carbon, Total Inorganic Carbon, and Total Organic Carbon for Simulated Tank 48H FBSR Products..... 
WSRC-TR-2003-00352, Rev. 0

\section{LIST OF ACRYNOMS}

\begin{tabular}{|c|c|}
\hline ADS & Analytic Development Section of SRTC \\
\hline CIF & Consolidated Incinerator Facility \\
\hline DTA & Differential Thermal Analysis \\
\hline DWPF & Defense Waste Processing Facility \\
\hline EMF & Electro Motive Force \\
\hline FBSR & Fluidized Bed Steam Reforming \\
\hline HLW & High Level Waste \\
\hline HPLC & High Pressure Liquid Chromotagraphy \\
\hline $\mathrm{IC}$ & Ion Chromatography \\
\hline ICP-ES & $\begin{array}{l}\text { Inductively Coupled Plasma - Emission } \\
\text { Spectroscopy }\end{array}$ \\
\hline INEEL & $\begin{array}{l}\text { Idaho National Engineering \& Environmental } \\
\text { Laboratory }\end{array}$ \\
\hline ITP & In Tank Processing \\
\hline LAW & Low Activity Waste \\
\hline LLRW & Low Level Radioactive Waste \\
\hline $\mathrm{MACT}$ & Maximum Achievable Concentration Technology \\
\hline $\mathrm{ML}$ & Mobile Laboratory \\
\hline PHA & Precipitate Hydrolysis Aqueous \\
\hline REDOX & REDuction/OXidation \\
\hline SBW & Sodium Bearing Waste \\
\hline SME & Slurry Mix Evaporator \\
\hline SPF & Studsvick Processing Facility \\
\hline SRAT & Sludge Receipt Adjustment Tank \\
\hline SRS & Savannah River Site \\
\hline SRTC & Savannah River Technology Center \\
\hline $\mathrm{TC}$ & Total Carbon \\
\hline THOR & THermal Organic Reduction \\
\hline $\mathrm{TIC}$ & Total Inorganic Carbon \\
\hline TOC & Total Organic Carbon \\
\hline TPB & Tetraphenylborate \\
\hline TRU & TRansUranic \\
\hline WAC & Waste Acceptance Criteria \\
\hline WIPP & Waste Isolation Pilot Plant \\
\hline WGSR & Water Gas Shift Reaction \\
\hline WSRC & Westinghouse Savannah River Co. \\
\hline XRD & X-ray Diffraction \\
\hline
\end{tabular}




\section{WSRC-TR-2003-00352, Rev. 0}

\section{EXECUTIVE SUMMARY}

An In Tank Processing (ITP) technology was developed at the Savannah River Site (SRS) to remove $\mathrm{Cs}^{137}$ from high level waste (HLW) supernates. During the ITP process monosodium titanate (MST) and sodium tetraphenylborate (NaTPB) were added to the salt supernate to adsorb $\mathrm{Sr}^{90} / \mathrm{Pu}^{238}$ and precipitate $\mathrm{Cs}^{137}$ as CsTPB, respectively. This process was demonstrated at the SRS in 1983. The demonstration produced 53,000 gallons of $2.5 \mathrm{wt} \% \mathrm{Cs}$ rich precipitate containing TPB, which was later washed and diluted to 250,000 gallons. This material is currently stored in SRS Tank 48H. The washed precipitate was to ultimately be disposed in borosilicate glass in the Defense Waste Processing Facility (DWPF). Due to safety concerns the ITP process was abandoned in 1998, and new technologies are being researched for $\mathrm{Cs}^{137}$ removal.

In order to make space in the SRS Tank farm, the Tank $48 \mathrm{H}$ waste must be removed. Therefore, the Tank $48 \mathrm{H}$ waste must be processed to reduce or eliminate levels of nitrates, nitrites, and sodium tetraphenyl borate (NaTPB) in order to reduce impacts of these species before it is vitrified at the DWPF. Fluidized Bed Steam Reforming (FBSR) is being considered as a candidate technology for destroying the nitrates and the NaTPB prior to melting. The Idaho National Engineering and Environmental Laboratory (INEEL) was tasked to perform a proof-of-concept steam reforming test to evaluate the technical feasibility for pretreating the Tank $48 \mathrm{H}$ waste. The crucible (bench scale) tests conducted at the Savannah River Technology Center (SRTC) were initiated to optimize and augment the parameters subsequently tested at the pilot scale at INEEL.

The purposes of the current study, organic destruction and downstream processing of $\mathrm{T} 48 \mathrm{H}$ waste slurry were fulfilled. TPB was destroyed in all 19 samples tested with the simulated FBSR process at operational temperatures $650-725^{\circ} \mathrm{C}$. A test temperature of $650^{\circ} \mathrm{C}$ optimized $\mathrm{NO}_{3}$ destruction during the formation of an $\mathrm{Na}_{2} \mathrm{CO}_{3}$ FBSR product. A test temperature of $725^{\circ} \mathrm{C}$ optimized $\mathrm{NO}_{3}$ destruction during formation of a sodium silicate FBSR product. Destruction of nitrate at $>99 \%$ was achieved with addition of sugar as a reductant at $1 \mathrm{X}$ stoichiometry and total organic carbon analyses indicated that excess reductant was not present in the FBSR product. The use of sugar at $1 \mathrm{X}$ stoichiometry appears to ensure that excess reductant is not contained in the FBSR product that would alter the REDuction/OXidation (REDOX) equilibrium of the DWPF melter, while simultaneously assuring that $\mathrm{NO}_{3}$ is destroyed adequately. Destruction of anitfoam with the simulated FBSR process was also achieved at operating temperatures between $650-725^{\circ} \mathrm{C}$ based on measured total organic carbon.

Sealed crucible tests with wet Tank 48H slurries ensured that the Water Gas Shift Reactions (WGSR) that occur in the FBSR process were duplicated in the bench scale tests. Sodium carbonate $\left(\mathrm{Na}_{2} \mathrm{CO}_{3}\right)$ was produced in all the bench scale studies in which $\mathrm{Na}_{2} \mathrm{CO}_{3}$ was the desired FBSR product phase. The $\mathrm{Na}_{2} \mathrm{CO}_{3}$ product was shown to be compatible with the DWPF melt process as it melts at $980^{\circ} \mathrm{C}$, as measured by differential thermal analysis. 
For all bench scale tests in which $\mathrm{Na}_{4} \mathrm{SiO}_{4}$ or $\mathrm{Na}_{2} \mathrm{SiO}_{3}$ was the desired FBSR product, a sodium silicate with a different stoichiometry $\left(\mathrm{Na}_{2} \mathrm{O}: \mathrm{SiO}_{2}\right)$ formed. This was determined to be a problem caused by water absorption of the finely particulate $\mathrm{SiO}_{2}$ additives used and the consumption of $\mathrm{SiO}_{2}$ by a potassium aluminate zeolite (faugesite) that formed during processing. Optimization of the $\mathrm{Na}_{2} \mathrm{O}: \mathrm{SiO}_{2}$ ratio of the Tank 48 feed is still needed. Formation of a sodium silicate (mixed with $\mathrm{Na}_{2} \mathrm{CO}_{3}$ or alone) is compatible with mixing the FBSR product into a DWPF feed tank or as an addition to the Slurry Mix Evaporator (SME) in place of frit for subsequent vitrification. The mixtures melted at temperatures of $1022^{\circ} \mathrm{C}$ and $1049^{\circ} \mathrm{C}$, respectively, as measured by differential thermal analysis. The melt temperatures of the $\mathrm{Na}_{2} \mathrm{CO}_{3}$ and $\mathrm{Na}_{2} \mathrm{SiO}_{3} \mathrm{FBSR}$ products $\left(980^{\circ} \mathrm{C}\right.$ and $1022-1049^{\circ} \mathrm{C}$ ) are low enough to ensure that addition of the FBSR product to the DWPF will not adversely impact melt rate. The impact of excess carbonate on the acid addition strategy in the DWPF Sludge Receipt and Adjustment Tank was not included in this study and still needs to be examined.

The recommended test parameters for the subsequent pilot scale testing of Tank $48 \mathrm{H}$ simulant at Idaho National Engineering and Environmental Laboratory (INEEL) were given by the following:

- $\mathrm{Al}_{2} \mathrm{O}_{3}$ bed media to avoid sticking and particle agglomeration

- $650^{\circ} \mathrm{C}$ at $1 \mathrm{X}$ stoichiometric sugar 3-48 hours residence time to make a $\mathrm{Na}_{2} \mathrm{CO}_{3}$ product (conditions for tests T48-5B and T48-13)

- $725^{\circ} \mathrm{C}$ at $1 \mathrm{X}$ stoichiometric sugar for 48 hours residence time for the $\mathrm{Na}_{2} \mathrm{SiO}_{3}$ product (conditions for test T48-14)

The sealed crucible studies and precarbonation of the feed demonstrated that bench scale studies can duplicate the complex reactions, especially the Water Gas Shift Reactions (WGSR) that occur in the FBSR process. This was monitored by adding $\mathrm{Fe}^{+3}$ compounds to the starting Tank 48 slurries and measuring the final $\mathrm{Fe}^{+2} / \Sigma \mathrm{Fe}$ ratio. Using a published correlation between the $\log$ of the oxygen fugacity $\left(\log f_{\mathrm{O}_{2}}\right.$ ) and the $\mathrm{Fe}^{+2} / \Sigma \mathrm{Fe}$ ratio the effective $\log f_{\mathrm{O}_{2}}$ inside the sealed crucibles could be calculated. Very negative values of the $\log f_{\mathrm{O}_{2}}$ indicated that there was virtually no oxygen present in the sealed crucibles. Knowing the $\log f_{\mathrm{O}_{2}}$ and the reaction temperatures, the associated $\log p_{\mathrm{H}_{2} \mathrm{O}} / p_{\mathrm{H}_{2}}$ and $\log p_{\mathrm{CO}_{2}} / p_{\mathrm{CO}}$ atmospheres in the sealed crucibles could be calculated from known correlations. The associated $\log p_{\mathrm{H}_{2} \mathrm{O}} / p_{\mathrm{H}_{2}}$ and $\log p_{\mathrm{CO}_{2}} / p_{\mathrm{CO}}$ atmospheres were a very positive indication that the WGSR was controlling the atmosphere inside the sealed crucibles and that oxygen was absent. 


\title{
DISPOSITION OF TANK 48H ORGANIC SLURRY BY FLUIDIZED BED STEAM REFORMING (FBSR) (U)
}

\author{
C.M. Jantzen \\ Savannah River Technology Center \\ Aiken, SC 29808
}

\subsection{INTRODUCTION}

An In Tank Processing (ITP) technology was developed at the Savannah River Site (SRS) to remove $\mathrm{Cs}^{137}$ from high level waste (HLW) supernates. During the ITP process monosodium titanate (MST) and sodium tetraphenylborate (NaTPB) were added to the salt supernate to adsorb $\mathrm{Sr}^{90} / \mathrm{Pu}$ and precipitate $\mathrm{Cs}^{137}$ as $\mathrm{CsTPB}$ respectively. This process was demonstrated at the SRS in 1983 [1]. The demonstration facility consisted of Tank $48 \mathrm{H}$, a 1.3 million gallon, carbon steel, underground HLW tank that had been retrofitted with chemical additional and process monitoring equipment. The actual demonstration was performed on a 500,000 gallon batch of radioactive salt supernate that was chemically treated and filtered. This produced 450,000 gallons of decontaminated filtrate, which was disposed of in saltstone, and 53,000 gallons of $2.5 \mathrm{wt} \% \mathrm{Cs}$ rich precipitate. The precipitate was washed to reduce the sodium concentrations and concentrate the TPB. The washed precipitate was stored in Tank $48 \mathrm{H}$ for ultimate disposal in borosilicate glass in the Defense Waste Processing Facility (DWPF).

The 1983 ITP process was considered a success and construction of a permanent ITP facility was started in 1985. In order to make the ITP waste compatible with the high temperature DWPF vitrification process, the benzene emitted from the ITP had to be destroyed. The ITP precipitate conditioning started with washing in the Late Wash Facility to remove non-radioactive salts and reduce nitrite concentration. This washing was to be followed by decomposition of the TPB to benzene and separation of the benzene from the aqueous waste in the DWPF Salt Cell. The benzene was to be burned in the SRS Consolidated Incinerator Facility (CIF) while the cesium, titanium, and boron rich residues were vitrified in the DWPF [2].

The permanent ITP facility initiated radioactive operation in September 1995. The first feed was 130,000 gallons of salt solution and 37,300 gallons of NaTPB to the heel of precipitate in Tank 48H that remained from the 1983 demonstration. During processing, benzene evolved in Tank $48 \mathrm{H}$ at higher rates than anticipated from decomposition of the NaTPB. Although the operational safety limit for benzene emission was never approached, the DOE initiated a stop work order and in 1998 abandoned the ITP project. Alternate technologies for $\mathrm{Cs}^{137}$ removal have been selected and demonstrated in laboratory testing. Operation of the Late Wash Facility and the DWPF Salt Cell facilities were abandoned and DWPF radioactive sludge vitrification commenced in 1996 without the ITP alkali boron contribution. 


\section{WSRC-TR-2003-00352, Rev. 0}

Currently Tank $48 \mathrm{H}$ has about 250,000 gallons of slurry which contains potassium and cesium tetraphenylborate (KTPB and CsTPB). Tank 48H needs to be returned to service by August 2005 in order to free up tank space in the high level waste (HLW) system [3]. The TPB organics in the Tank $48 \mathrm{H}$ slurry need to be removed or destroyed before this slurry is pumped out and processed downstream.

In 2001, a team evaluated processing options that would return Tank $48 \mathrm{H}$ to routine HLW service [4]. The team used a Systems Engineering approach to evaluate 40 alternatives. While most options decomposed the organics with catalysts, oxidants, and/or acids, one thermal treatment was recommended for further investigation, i.e. Fluidized Bed Steam Reforming (FBSR).

The candidate thermal process for the Tank $48 \mathrm{H}$ organic destruction, FBSR, is capable of destroying the organic KTPB and CsTPB at moderate temperature and converting it to $(\mathrm{Cs}, \mathrm{Na})_{2} \mathrm{O}$ or $(\mathrm{Cs}, \mathrm{Na})_{2} \mathrm{CO}_{3}$ or $(\mathrm{Cs}, \mathrm{Na}) \mathrm{SiO}_{3}, \mathrm{CO}_{2}$ gas, and $\mathrm{H}_{2} \mathrm{O}$ in the form of steam $[5,6]$. The high nitrate and nitrite content of the Tank $48 \mathrm{H}$ slurry will be converted to $\mathrm{N}_{2}$ during FBSR processing, thereby minimizing $\mathrm{NO}_{\mathrm{x}}$ emissions during processing. Any organics are oxidized to $\mathrm{CO}_{2}$ instead of $\mathrm{CO}$ during processing. The FBSR can be electrically heated (pilot scale units) or operated in an auto-thermal mode, whereby the energy needs are supplied by the incoming superheated steam and by the oxidation of organics from the waste and carbon reductants. For production scale units, auto-thermal steam reforming is the preferred mode of operation. Since there is no open flame as in incineration and since the product emissions are $\mathrm{CO}_{2}$ and $\mathrm{N}_{2}$ instead of $\mathrm{CO}$ and $\mathrm{NO}_{\mathrm{x}}$, the FBSR process is Clean Air Act and Maximum Achievable Concentration Technology (MACT) compliant. The solid oxide or mineral phases produced, e.g. $(\mathrm{Cs}, \mathrm{Na})_{2} \mathrm{O}$ or $(\mathrm{Cs}, \mathrm{Na})_{2} \mathrm{CO}_{3}$ or $(\mathrm{Cs}, \mathrm{Na}) \mathrm{SiO}_{3}$, are considered compatible with subsequent processing of the FBSR remediated Tank $48 \mathrm{H}$ feed to borosilicate glass in the Defense Waste Processing Facility (DWPF).

The purposes of the current study were to demonstrate the following objectives with a Tank 48H simulant:

- destruction of TPB with the FBSR process operating between $650-725^{\circ} \mathrm{C}$

- destruction of nitrate at $>99 \%$ with addition of sugar as a reductant

- destruction of anitfoam with the FBSR process operating between $650-725^{\circ} \mathrm{C}$

- formation of $\mathrm{Na}_{2} \mathrm{CO}_{3}$ FBSR product to be compatible with mixing the FBSR product into a DWPF feed tank for subsequent vitrification

- formation of a $\mathrm{Na}_{2} \mathrm{SiO}_{3}$ or $\mathrm{Na}_{4} \mathrm{SiO}_{4}$ FBSR product to be compatible with mixing the FBSR product into a DWPF feed tank or as an addition to the Slurry Mix Evaporator (SME) in place of frit for subsequent vitrification

- assessment of the melting temperature of the $\mathrm{Na}_{2} \mathrm{CO}_{3}$ and $\mathrm{Na}_{2} \mathrm{SiO}_{3} \mathrm{FBSR}$ products to ensure that addition of the FBSR product to the DWPF will not adversely impact melt rate

- optimization of the amount of reductant to ensure that excess reductant was not contained in the FBSR product that would alter the REDuction/OXidation (REDOX) equilibrium of the DWPF melter [7] 
- optimization of test parameters for subsequent pilot scale testing of Tank $48 \mathrm{H}$ simulant at Idaho National Engineering and Environmental Laboratory (INEEL)

- demonstration that bench scale studies in crucibles can duplicate the complex reactions in the FBSR process

\subsection{FLUIDIZED BED STEAM REFORMING (FBSR)}

\subsection{Demonstrations by THOR $^{\mathrm{sm}}$}

Studsvik built and tested a commercial Low-Level Radioactive Waste (LLRW) FBSR Processing Facility in Erwin, TN, in 1999 [8]. In January 2000, the throughput rate was increased and commercial operation commenced [5]. The Studsvik Processing Facility (SPF) has the capability to safely and efficiently receive and process a wide variety of solid and liquid LLRW streams including: ion exchange resins, charcoal, graphite, sludge, oils, solvents, and cleaning solutions with contact radiation levels of up to 100R/hr. The licensed and heavily shielded SPF can receive and process liquid and solid LLRWs with high water and/or organic content.

The Erwin facility employs the THermal Organic Reduction $\left(\mathrm{THOR}^{\mathrm{sm}}\right)$ process, developed by Studsvik, which utilizes pyrolysis*/steam reforming technology. THOR ${ }^{\mathrm{sm}}$ reliably and safely processes a wide variety of LLRWs in a unique, moderate temperature $\left(\sim 700^{\circ} \mathrm{C}\right)$, dual-stage, pyrolysis/reforming, fluidized bed treatment system. The reforming process has demonstrated effectiveness in volatilizing/combusting organics and separating sulfur and halogens from inorganic waste materials. Of special relevance is the capability of the $\mathrm{THOR}^{\mathrm{sm}}$ technology to convert nitrates to nitrogen and sodium salts to sodium compounds that are suitable for direct disposal and/or subsequent vitrification.

In February 2002, THOR $^{\mathrm{sm}}$ demonstrated the capability of producing sodium aluminosilicate waste forms for Hanford's sodium-bearing low activity waste (LAW) [6]. Non-radioactive simulants of $8.1 \mathrm{M} \mathrm{Na}^{+}$were successfully tested in a 6-inch pilot scale facility that was located at Hazen Research in Colorado. ${ }^{\dagger}$ Other demonstrations performed by Hazen showed that LAW waste could be transformed into $\mathrm{Na}_{2} \mathrm{CO}_{3}$, $\mathrm{NaAlO}_{2}$, or $\mathrm{Na}_{2} \mathrm{SiO}_{3}$ feed material for the LAW Hanford melter (Table 1). Addition of no solid co-reactant will yield a sodium carbonate product. Sodium combines with carbon dioxide in the reformer gases to provide a sodium carbonate product. The generation of sodium carbonate in this type of application has been studied since the 1950s in fluid bed denitration systems [5]. Addition of a $\mathrm{Al}(\mathrm{OH})_{3}$ co-reactant will provide an $\mathrm{NaAlO}_{2}$ product, addition of $\mathrm{SiO}_{2}$ will provide an $\mathrm{Na}_{2} \mathrm{SiO}_{3}$ product. Addition of kaolin clay will provide an $\mathrm{NaAlSiO}_{4}$ product (Table 1). The latter has been shown to perform well as a final waste form $[6,9]$. Testing on Hanford LAW surrogates has shown that over $95 \%$ of

* Pyrolysis chemically decomposes organic materials by heat in the absence of oxygen, e.g. $\mathrm{C}_{\mathrm{x}} \mathrm{H}_{\mathrm{y}}+$ Heat $\rightarrow \mathrm{CH}_{4}+\mathrm{C}$.

$\dagger \quad$ The solution was diluted to $5.2 \mathrm{M} \mathrm{Na}^{+}$to homogenize the feed before processing due to the observation of precipitated solids in the feed tank 
the sulfur compounds, fluorides and chlorides in the waste feed react in the steam reformer with the clay co-reactant and become an integral part of the final $\mathrm{NaAlSiO}_{4}$ waste product's crystalline structure [5].

In November 2002, THOR $^{\mathrm{sm}}$ was contracted to demonstrate the FBSR technology to produce a final waste form for Idaho National Engineering and Environmental Laboratory acidic and radioactive Sodium-Bearing Waste (SBW) [10]. This demonstration successfully converted the high sodium waste to an $\mathrm{Na}_{2} \mathrm{CO}_{3}$ product that met the Waste Isolation Pilot Plant (WIPP) Waste Acceptance Criteria (WAC) for transuranic (TRU) waste. During the demonstration data were collected to determine the nature and characteristics of the product, the operability of the technology, the composition of the off-gases, and the fate of key radionuclides (cesium and technetium) and volatile mercury compounds. The product contained a significant fraction of elemental carbon residues. Mercury was quantitatively stripped from the product but cesium, rhenium (Tc surrogate), and the heavy metals were retained. Nitrates were not detected in the product and $\mathrm{NO}_{\mathrm{x}}$ destruction exceeded $98 \%$. The demonstration was considered successful and no bed agglomeration was experienced [10]. The steam reformer off-gas was monitored and it was determined that no $\mathrm{O}_{2}$ was present. The offgas was mostly $(76 \%) \mathrm{H}_{2} \mathrm{O}$ (wet, $\mathrm{N}_{2}$-free basis). $\mathrm{CO}$ levels averaged $1.3 \%$, while the measured $\mathrm{CH}_{4}$ levels averaged 0.1 . The $\mathrm{O}_{2}$ and $\mathrm{H}_{2}$ levels in the off-gas were low enough that they did not pose a significant threat of forming an explosive mixture.

Table 1. THOR ${ }^{\mathrm{sm}}$ Pilot Scale Demonstrations Performed at Hazen Research

\begin{tabular}{|c|l|l|l|}
\hline $\begin{array}{c}\text { Number of } \\
\text { Pilot } \\
\text { Demon- } \\
\text { strations }\end{array}$ & $\begin{array}{c}\text { Solid } \\
\text { Additive }\end{array}$ & \multicolumn{1}{|c|}{ Mineral Product } & \multicolumn{1}{c|}{ Purpose } \\
\hline 5 & Clay & $\begin{array}{l}\text { Sodium aluminosilicates that } \\
\text { can stabilize problematic } \\
\text { anions such as Cl, F, and } \mathrm{SO}_{4}\end{array}$ & $\begin{array}{l}\text { Stabilization in final mineral waste } \\
\text { form }\end{array}$ \\
\hline 3 & Sand & Sodium silicate & $\begin{array}{l}\text { Dehydration, denitration, organic } \\
\text { destruction of LAW waste for } \\
\text { subsequent vitrification and/or } \\
\text { dehydration of melter blowdown } \\
\text { for recycle to a melter }\end{array}$ \\
\hline 2 & Al(OH) 3 & Sodium aluminate & $\begin{array}{l}\text { Dehydration, denitration, organic } \\
\text { destruction of LAW waste for } \\
\text { subsequent vitrification and/or } \\
\text { dehydration of melter blowdown } \\
\text { for recycle to a melter }\end{array}$ \\
\hline 3 & None & Sodium carbonate & $\begin{array}{l}\text { Dehydration, denitration, organic } \\
\text { destruction of LAW waste for } \\
\text { subsequent vitrification and/or } \\
\text { dehydration of melter blowdown } \\
\text { for recycle to a melter }\end{array}$ \\
\hline
\end{tabular}




\section{WSRC-TR-2003-00352, Rev. 0}

\subsection{Operation and Flowsheet Options}

In the THOR ${ }^{\mathrm{sm}}$ FBSR process, a granular/particle bed material is fluidized with low pressure superheated steam. The tank waste is mixed in a batch/feed tank with select coreactants, including the additives necessary to make the final product into any of the applications listed in Table 1. The FBSR feed slurry is injected into the bottom of the fluidized bed just above the fluid gas (steam) distributors. Additional solid co-reactants, such as granular carbon and iron oxide reductants, are co-fed to the fluidized bed. The lower zone of the fluid bed is operated in strongly reducing conditions to facilitate reduction of nitrates and nitrites to nitrogen gas. The upper zone of the fluid bed is operated under oxidizing condition by injection of oxygen into the upper zone of the fluidized bed. The oxidizing zone converts residual carbon reductants and organics into carbon dioxide and water vapor. Several chemical and physical reactions take place in the steam reformer [5]:

- Evaporation of all liquid.

- Conversion of all sodium, potassium, and aluminum in the waste feed into a stable mineralized product (choices are given in Table 1). The mineral product contains any radionuclides and inorganic elements in the waste feed stream in the form of oxides, carbonates, aluminates and/or silicates.

- Denitration of the nitrates and nitrites $(>99 \%)$ in the waste feed into nitrogen gas by the carbon and metal reductant solids and $\mathrm{CO}$ and $\mathrm{H}_{2}$ gases in the bed.

- Conversion of organics into $\mathrm{CO}_{2}$ by a two step process. First organics are decomposed into light volatile hydrocarbons such as methane, carbon monoxide, hydrogen, carbon dioxide, and water in the lower zone of the reformer bed. In the upper zone of the reformer bed, oxygen is injected to more fully oxidize the gaseous constituents. The off-gas stream from the reformer consists of water vapor, carbon dioxide, nitrogen, fine particles of solid product, minor carbon particle carryover, and small quantities of acid gases not converted to a mineralized form in the reformer.

- Reduction and stabilization of any hazardous metals. For example hazardous metals such as $\mathrm{Cr}^{+6}$ are reduced to a non-hazardous valence state, e.g. $\mathrm{Cr}^{+3}$, and are chemically bound in the solid product. Other hazardous metals, such as lead, have also been determined to be chemically bound in the solid product.[6]

The THOR ${ }^{\mathrm{sm}} \mathrm{FBSR}$ is typically operated under vacuum at $700^{\circ} \mathrm{C}$ to $750^{\circ} \mathrm{C}$. A typical flowsheet is shown in Figure 1. The $>99 \%$ conversion of nitrates to nitrogen requires the following [5]:

- $\quad$ fluidized bed material with high surface area and high heat transfer capability

- high energy generation to evaporate and superheat the water in a typical waste feed

- strongly reducing conditions that are provided by the reductants added to the process 


\section{WSRC-TR-2003-00352, Rev. 0}

- superheated steam that generates carbon monoxide and hydrogen inside the bed from the reaction of steam with the carbon reductant(s)

- co-reactant(s) that convert the alkali metals ( $\mathrm{Na}$ and $\mathrm{K}$ ) into higher melting point mineral compounds to prevent formation of low melting point eutectic salts and unwanted bulk agglomerations in the fluid bed.

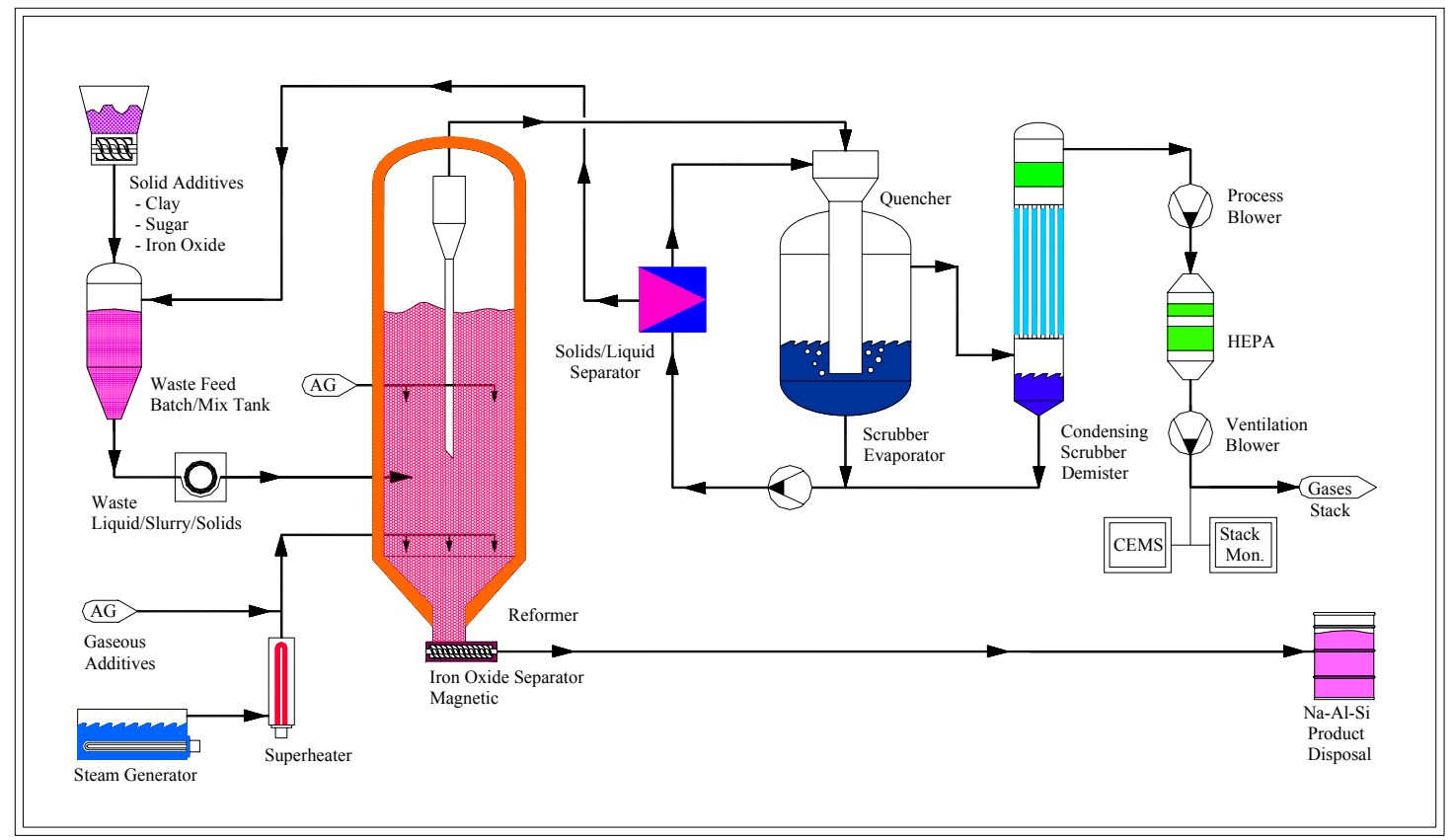

Figure 1 Typical FBSR flowsheet proposed by THOR for DOE Tank wastes [5].

The fluidized bed material can include ceramic media and/or reformed product granules/powders. The incoming waste feed coats the fluidized particles and is instantly dried. The large active surface of dried nitrates readily reacts with the hot carbon reductant particles, carbon monoxide and hydrogen gases, and the reduced metal and metal oxides particles in the fluidized bed. Hydrogen and $\mathrm{CO}$ are formed by the water gas reaction (Equation 1) and the steam reforming process (Equation 2). The $\mathrm{CO}$ in the gaseous mixture resulting from Equation 1 and Equation 2 can be made to react with more water in the water gas shift reaction (WGSR) given in Equation 3. These reactions are important sources of heat that facilitate the dehydratrion, denitration, and reaction of the waste plus additive mixtures.

Equation $1 \quad \mathrm{C}(\mathrm{s})+\mathrm{H}_{2} \mathrm{O}(\mathrm{g}) \rightarrow \mathrm{CO}(\mathrm{g})+\mathrm{H}_{2}(\mathrm{~g})$

Equation $2 \quad \mathrm{CH}_{4}(\mathrm{~g})+\mathrm{H}_{2} \mathrm{O}(\mathrm{g}) \rightarrow \mathrm{CO}(\mathrm{g})+3 \mathrm{H}_{2}(\mathrm{~g})$

Equation $3 \quad \mathrm{H}_{2} \mathrm{O}(\mathrm{g})+\mathrm{CO}(\mathrm{g}) \rightarrow \mathrm{H}_{2}(\mathrm{~g})+\mathrm{CO}_{2}$ 


\section{WSRC-TR-2003-00352, Rev. 0}

Free hydrogen promotes radical generation and chain reaction propagation in the bed and gaseous particle disengaging freeboard section. Steam also oxidizes all carbon-donating solids, including char. During the INEEL SBW steam reformer demonstrations sugar was used as the reductant along with activated carbon. This facilitated the decomposition of nitrates in the feed and reduced $\mathrm{NO}_{\mathrm{x}}$ to elemental nitrogen. Excess sucrose pyrolyzed, at the process temperatures, producing a finely divided carbon char. The activated carbon and the char reacted with the process steam to produce carbon monoxide and hydrogen gas via Equation 3.

Even though carbon monoxide and hydrogen are produced in equimolar quantities by the water-gas shift reaction (Equation 3), a significant portion of the carbon monoxide reacts with other gaseous species. Examples of this are the methanation reaction, and reactions with $\mathrm{NO}_{\mathrm{x}}$ to form nitrogen gas. The WGSR (Equation 3) is, however, the most dominant and results in molar hydrogen concentrations that are several times higher than the molar concentration of carbon monoxide [10].

$$
\begin{aligned}
& \mathrm{CO}+3 \mathrm{H}_{2} \rightarrow \mathrm{CH}_{4}+\mathrm{H}_{2} \mathrm{O} \\
& \mathrm{CO}+\mathrm{NO}_{2} \rightarrow \mathrm{CO}_{2}+\mathrm{NO} \\
& \mathrm{CO}+\mathrm{NO} \rightarrow \mathrm{CO}_{2}+1 / 2 \mathrm{~N}_{2}
\end{aligned}
$$

Hydrogen is believed to be more effective in reducing $\mathrm{NO}_{\mathrm{x}}$ to elemental nitrogen than $\mathrm{CO}$, although reactions with intermediate sugar pyrolysis products may also contribute significantly to $\mathrm{NO}_{\mathrm{x}}$ destruction [10]. Examples of the hydrogen reactions are as follows:

$$
\begin{aligned}
& \mathrm{H}_{2}+\mathrm{NO}_{2} \rightarrow \mathrm{H}_{2} \mathrm{O}+\mathrm{NO} \\
& \mathrm{H}_{2}+\mathrm{NO} \rightarrow \mathrm{H}_{2} \mathrm{O}+1 / 2 \mathrm{~N}_{2}
\end{aligned}
$$

Enrichment of the fluidizing steam with $\mathrm{CO}_{2}$ may help convert the product to a carbonate phase; however, this is counter-productive in terms of the water gas shift reaction (Le Chatelier's Principal). Thus, if high partial pressures of $\mathrm{CO}_{2}$ are desired, then it is preferable to add more solid carbon [11].

Experience has shown that thermal denitration without the presence of a reductant will result in reduction of residual nitrates in the solid product of only up to $90 \%$, i.e. $90 \%$ of the incoming nitrates are thermally volatized leaving approximately $10 \%$ of incoming nitrates in the final solid waste product. The typical total $\mathrm{NO}_{\mathrm{x}}$ content of other thermal denitration processes, without use of a reductant, will range from 20,000 ppm to over 50,000 ppm total $\mathrm{NO}_{\mathrm{x}}$ in the process off-gas [5]. The addition of carbonaceous reductants to nitrate wastes in a thermal denitration process has shown substantial improvements with up to $98 \%$ nitrate reduction in the solid product and a corresponding reduction of total $\mathrm{NO}_{\mathrm{x}}$ in the process off-gas to $3,000 \mathrm{ppm}$ to $10,000 \mathrm{ppm}$. A further order of magnitude improvement in nitrate conversion is possible by use of both carbonaceous and metal-based iron oxide reductants in the fluid bed [5]. 


\section{WSRC-TR-2003-00352, Rev. 0}

A significant benefit of the $\mathrm{THOR}^{\mathrm{sm}}$ steam reforming process is that the facility produces zero-liquid releases. The Erwin facility has been commercially operational at full-scale for three years with no release of liquids [5]. All water is released as water vapor out the monitored ventilation stack. All organics are processed through the reformer.

Trace radioactive particulates remaining in the off-gas stream after the quencher/scrubber/evaporator are removed by HEPA filtration prior to discharge of gases to the atmosphere. Volatile radionuclides processed at Erwin include tritium, carbon ${ }^{14}$ and iodine [5]. If desired, the iodine can be adsorbed by granular activated carbon media downstream of the HEPA filter. It is not normally feasible to remove the carbon ${ }^{14}$, as it will have been converted to carbon ${ }^{14}$ dioxide and cannot be easily separated from nonradioactive carbon dioxide. Any tritium is converted to water vapor in the process. If mercury is present in the waste feed, a mercury removal capability will need to be designed in the off-gas system as mercury will volatize to the gas phase during thermal treatment [5]. $\mathrm{THOR}^{\mathrm{sm}}$ anticipates that a commercially available granular activated carbon or gold impregnated media can be placed downstream of the HEPA filter to remove essentially all volatile mercury from the off-gas stream [5].

Table 2. Discharges and Emissions from a Production-Scale THOR ${ }^{\mathrm{sm}}$ Steam Reforming Process for Tank Wastes [5]

\begin{tabular}{|c|c|}
\hline Material & Discharge/Emission \\
\hline SOx & $<10 \mathrm{ppm}$ in off-gas at stack \\
\hline $\begin{aligned} \text { NOx: } & \\
& -\mathrm{NO}_{2} \\
& -\mathrm{NO} \\
& -\mathrm{N}_{2} \mathrm{O}, \text { Others }\end{aligned}$ & $\begin{aligned} & <5 \mathrm{ppm} \text { in off-gas at stack } \\
< & 25 \mathrm{ppm} \text { in off-gas at stack } \\
< & 25 \mathrm{ppm} \text { in off-gas at stack }\end{aligned}$ \\
\hline $\mathrm{HCl}$ & $<10 \mathrm{ppm}$ in off-gas at stack \\
\hline $\mathrm{HF}$ & $<2$ ppm in off-gas at stack \\
\hline $\mathrm{CO}$ & $<25 \mathrm{ppm}$ in off-gas at stack \\
\hline $\begin{array}{l}\text { - } \text { Carbon }^{14} \\
\text { - Iodine } \\
\text { - Other }\end{array}$ & $\begin{array}{l}\text { Tritium is converted to water vapor and is released up the monitored } \\
\text { stack. An optional off-gas condenser can be provided to fully } \\
\text { condense water and discharge water and tritium to groundwater if } \\
\text { required. } \\
\text { Carbon }{ }^{14} \text { is converted to carbon dioxide and is released up the } \\
\text { monitored stack. } \\
\text { Iodine will be released up the stack unless adsorption media is placed } \\
\text { downstream of the HEPA filter to remove iodine from the off-gas. } \\
>99.99 \% \text { retained in the solid product }\end{array}$ \\
\hline Mercury & $\begin{array}{l}\text { Mercury is removed from the off-gas by means of adsorption media } \\
\text { downstream of HEPA filters. }\end{array}$ \\
\hline Scrubber Salts & $\begin{array}{l}\text { Scrubber salts are recycled to the reformer waste feed. There are no } \\
\text { scrubber salt solution or dried salt discharges. }\end{array}$ \\
\hline $\mathrm{H}_{2} \mathrm{O}$ & $\begin{array}{l}\text { Water is evaporated and discharged through the plant stack as water } \\
\text { vapor. Process has zero-liquid releases. }\end{array}$ \\
\hline
\end{tabular}




\section{WSRC-TR-2003-00352, Rev. 0}

\subsection{EXPERIMENTAL}

A simulant of the Tank $48 \mathrm{H}$ solution was prepared according to Table 3 . This slurry has approximately $13.7 \mathrm{wt} \%$ solids after the TPB decomposes. In order to make a minimum of 30 grams of solid product, a test batch consisted of 218.66 grams of simulant to which $5 \mathrm{wt} \% \mathrm{Fe}_{2} \mathrm{O}_{3}$ was added as $\mathrm{Fe}\left(\mathrm{NO}_{3}\right)_{3} \bullet 9 \mathrm{H}_{2} \mathrm{O}(0.38 \mathrm{gms})$. Antifoam (IIT Corp. B52) was added at $100 \mathrm{ppm}$ antifoam per wt\% solids [12] or 0.21 grams per batch. The $\mathrm{Fe}_{2} \mathrm{O}_{3}$ was added to provide an indicator of the REDuction/OXidation (REDOX) equilibrium that the sample experienced in sealed crucibles inside the oven. Having $\sim 5 \mathrm{wt} \% \mathrm{Fe}_{2} \mathrm{O}_{3}$

present enabled the $\mathrm{Fe}^{+2} / \Sigma \mathrm{Fe}$ ratio of the solid product sample to be measured from which the oxygen fugacity, $f_{\mathrm{O}_{2}}$, of the reaction atmosphere could be determined. All samples were sent to the Savannah River Technology Center (SRTC) Mobile Laboratory (ML) for $\mathrm{Fe}^{+2} / \Sigma \mathrm{Fe}$ analysis by the Baumann method $[13,14]$.

Table 3 Tank 48H Simulant Recipe

\begin{tabular}{|c|c|}
\hline Species & $\mathrm{M} / \mathrm{L}$ \\
\hline & 0.0728 \\
\hline $\mathrm{NaTPB}$ & 1.8425 \\
\hline $\mathrm{NaOH}$ & 0.4709 \\
\hline $\mathrm{NaNO}_{2}$ & 0.2753 \\
\hline $\mathrm{NaNO}_{3}$ & 0.1295 \\
\hline $\mathrm{Na}_{2} \mathrm{CO}_{3}$ & 0.1118 \\
\hline $\mathrm{NaAlO}_{2}$ & 0.0071 \\
\hline $\mathrm{Na}_{2} \mathrm{SO}_{4}$ & 0.0077 \\
\hline $\mathrm{Na}_{3} \mathrm{PO}_{4}$ & 0.0088 \\
\hline $\mathrm{NaCl}$ & 0.0059 \\
\hline $\mathrm{NaF}_{3}$ & 0.0779 \\
\hline
\end{tabular}

The $\mathrm{T} 48 \mathrm{H}$ simulants were batched into stainless steel beakers. The slurry was carbonated with dry ice to convert the $\mathrm{NaOH}$ to $\mathrm{Na}_{2} \mathrm{CO}_{3}$ until a $\mathrm{pH}$ of $\sim 9.5$ was reached. This "acidification" from $\mathrm{pH} 13.3$ to 9.5 also minimized foaming of the slurry (Figure 2). This ensured that once the carbonated material was put into a sealed crucible that a $\mathrm{CO}_{2}$ atmosphere would be maintained. This served to duplicate the control of the atmosphere in the FBSR with $\mathrm{CO}_{2}$ gas.

The reductant of choice was sucrose. A test matrix (Table 4) was developed that varied three different levels of reductant based on the following stoichiometric equations:

Equation $4 \quad \mathrm{C}_{12} \mathrm{H}_{22} \mathrm{O}_{11}+9.6 \mathrm{NaNO}_{3} \rightarrow 7.2 \mathrm{CO}_{2}+11 \mathrm{H}_{2} \mathrm{O}+4.8 \mathrm{Na}_{2} \mathrm{CO}_{3}+4.8 \mathrm{~N}_{2}$

Equation $5 \quad \mathrm{C}_{12} \mathrm{H}_{22} \mathrm{O}_{11}+16 \mathrm{NaNO}_{2} \rightarrow 4 \mathrm{CO}_{2}+11 \mathrm{H}_{2} \mathrm{O}+8 \mathrm{Na}_{2} \mathrm{CO}_{3}+8 \mathrm{~N}_{2}$ 


\section{WSRC-TR-2003-00352, Rev. 0}

Where the stoichiometric ratio of $[\mathrm{C}]:[\mathrm{N}]$ for nitrate species is $12 / 9.6=1.25$ (Equation 4 ) and 12/16 $=0.75$ for nitrite species (Equation 5). The desired [C]:[N] ratio is 0.97 which is computed by adding the following two terms together: 1.25 times the moles of $\mathrm{NO}_{3}$ from all sources plus 0.75 times the moles of $\mathrm{NO}_{2}$ from all sources for $0.22 \mathrm{~L}$ (the size of a sample batch) of the simulant given in Table 3 and the $\mathrm{Fe}\left(\mathrm{NO}_{3}\right)_{3} \bullet 9 \mathrm{H}_{2} \mathrm{O}$ added as a REDOX indicator. The final moles of sucrose to add was then calculated as follows:

Sucrose $(\mathrm{M})=($ Desired stoichiometric factor $) *([\mathrm{C}]:[\mathrm{N}]$ ratio of $0.22 \mathrm{~L}$ feed $) *\left(\right.$ moles $\mathrm{NO}_{3}+\mathrm{NO}_{2}$ in feed $) / 12$

In the test matrix (Table 4) three different levels of sucrose (none, $1 / 2 \mathrm{X}$ stoichiometric, and $1 \mathrm{X}$ stoichiometric) and three different reaction times (1/2 hour, 3 hours, and 48 hours) were tested. The reaction times in a static crucible that could reproduce the chemistry of an active FBSR environment was a complete unknown. High purity (99.999\%) $\mathrm{Al}_{2} \mathrm{O}_{3}$ crucibles were used to simulate $\mathrm{Al}_{2} \mathrm{O}_{3}$ bed material and to determine if the FBSR product was adhering to the simulated bed media. Temperatures of $650^{\circ} \mathrm{C}$ and $725^{\circ} \mathrm{C}$ were tested to see which levels of reductant optimized the WGSR (Equation 3) at which temperatures.

The known melt temperatures of alumina containing FBSR products are high. Nepheline $\left(\mathrm{NaAlSiO}_{4}\right)$ melts incongruently to carnegieite at $1280^{\circ} \mathrm{C}$ which then does not melt until $1526^{\circ} \mathrm{C}$ [15] if pure. The FBSR $\mathrm{NaAlO}_{2}$ has a known melt temperature of $1680^{\circ} \mathrm{C}$ [16] if pure. The melt temperatures may be $100-200^{\circ} \mathrm{C}$ lower if other alkali or alkaline earth or iron substitutions are incorporated into the FBSR sodium aluminate containing products. The high melting temperature, refractory nature of these FBSR products was felt to be inappropriate for subsequent processing of the Tank 48H FBSR product in DWPF, e.g. high $\mathrm{Al}_{2} \mathrm{O}_{3}$ containing FBSR products could impact DWPF's melt rate and attainment rate. Hence, the lower melting $\mathrm{Na}_{2} \mathrm{CO}_{3}$ and $\mathrm{Na}_{2} \mathrm{SiO}_{3}$ FBSR products were targeted for study. Since the feed was already carbonated nothing needed to be added to the samples to optimize the $\mathrm{Na}_{2} \mathrm{CO}_{3}$ product. Precipitated silica was added to the tests where the desired final FBSR product was $\mathrm{Na}_{2} \mathrm{SiO}_{3}$ or $\mathrm{Na}_{4} \mathrm{SiO}_{4}$.

The carbonated slurries were dried to peanut butter consistency per procedure ITS-00052, Rev. 0 [17]. This ensures that some $\mathrm{H}_{2} \mathrm{O}$ remains in the sample to create steam for the WGSR. Sealed crucible reaction is achieved by sealing $\mathrm{Al}_{2} \mathrm{O}_{3}$ crucibles with nepheline $\left(\mathrm{NaAlSiO}_{4}\right)$ gel that melts at a temperature lower than that at which the WGSR occurs. This causes the crucible to seal before the slurry reacts so that air inleakage does not occur during reaction. This is extremely important as air inleakage will alter the reactions as monitored by the measured $\mathrm{REDOX}$ ratio, $\mathrm{Fe}^{2+} / \Sigma \mathrm{Fe}$, and allow oxidizers and reductants to escape rather than reacting with the species in the slurry and additives.

The sealed samples were placed in a calibrated furnace at the test temperature designated in the test matrix. This generated a combined atmosphere of steam, $\mathrm{CO}$ from decomposition of the sucrose, and $\mathrm{CO}_{2}$ from decomposition of the $\mathrm{Na}_{2} \mathrm{CO}_{3}$ formed during carbonation thus duplicating the CO-steam environment necessary for the WGSR (Equation 3) and $\mathrm{CO}_{2}$. The furnace was purged with $99.99 \%$ Ar to ensure that no $\mathrm{O}_{2}$ 
mixed with any $\mathrm{H}_{2}$ that diffused through the crucible seal thus eliminating any concern of explosive gas mixtures and duplicating the deoxygenated high $\mathrm{CO}_{2}$ atmosphere of the FBSR process.
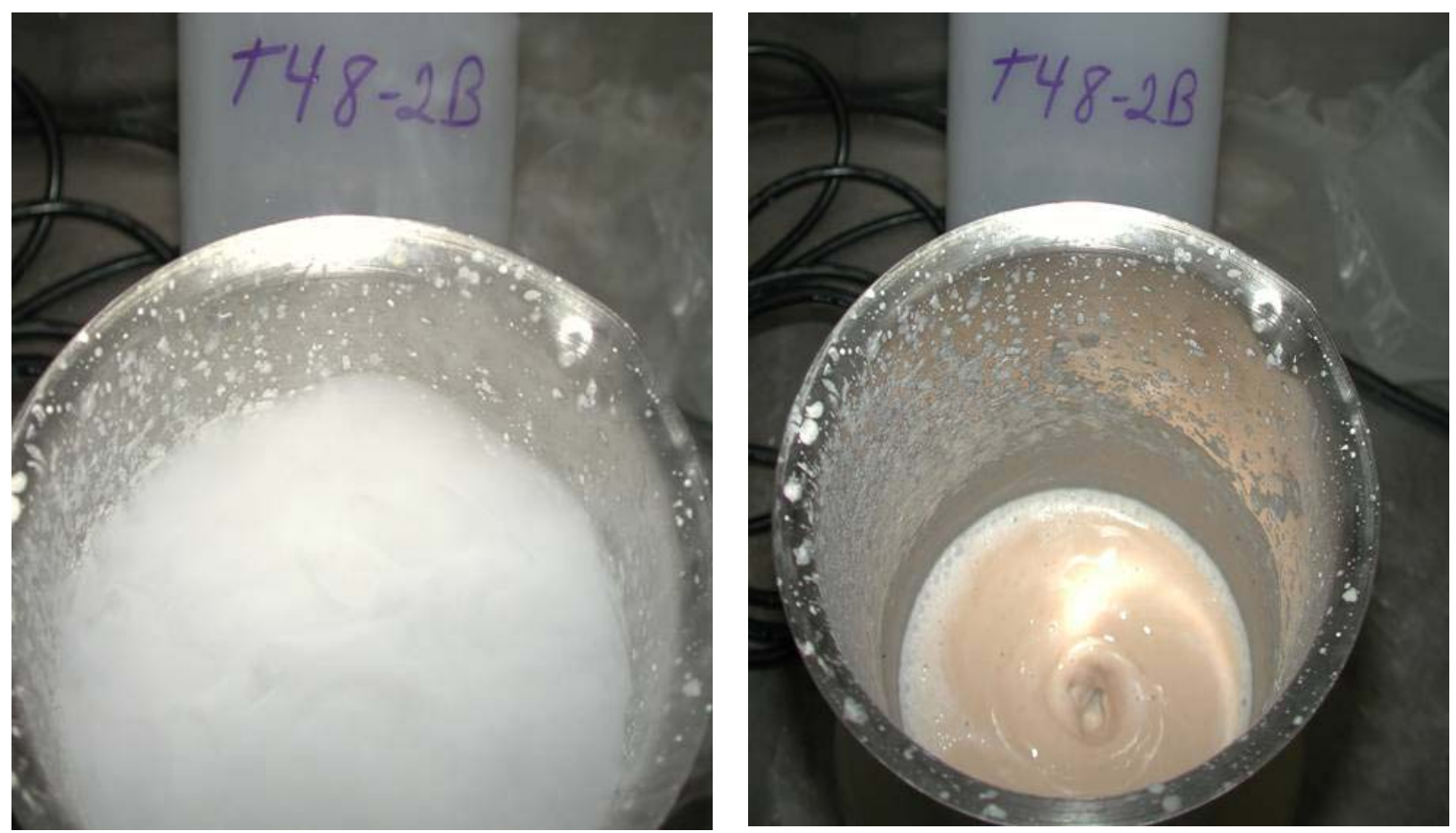

Figure 2. Tank 48H simulated slurry during (left) and after (right) carbonation. Note foaming in sample before and during carbonation.

Samples were analyzed by X-ray diffraction (XRD) to determine if the desired FBSR product was achieved. Samples were measured by High Pressure Liquid Chromatography (HPLC) after digestion to determine if the TPB was adequately destroyed by the FBSR reactions. Secondary reaction products such as $3 \mathrm{~PB}$ and $2 \mathrm{~PB}$ were also analyzed for. Total carbon (TC), Total Inorganic Carbon (TIC), and Total Organic Carbon (TOC) were also analyzed.

Samples were measured for $\mathrm{Fe}^{+2} / \Sigma \mathrm{Fe}$ in duplicate to determine the $f_{\mathrm{O}_{2}}$ of the atmosphere inside the $\mathrm{Al}_{2} \mathrm{O}_{3}$ crucible during reaction. Samples were measured by Ion Chromatography (IC) for $\mathrm{NO}_{2}, \mathrm{NO}_{3}, \mathrm{~F}, \mathrm{Cl}$ and $\mathrm{SO}_{4}$ to determine the fate of these anions and the percent nitrate destruction. For those samples that the desired FBSR product was a silicate, samples were were dissolved using a $\mathrm{LiBO}_{2}$ fusion and the solution analyzed by Inductively Coupled Plasma - Emission Spectroscopy (ICP-ES) for Na, K, and Si to determine if the correct ratios of silica additive had been achieved during experimentation. 
WSRC-TR-2003-00352, Rev. 0

Table 4 Simulated T48H Steam Reformer Optimization Matrix, X-Ray Diffraction Analysis, HPLC Analysis, and Nitrate Destruction

\begin{tabular}{|c|c|c|c|c|c|c|c|c|c|c|c|c|c|}
\hline Test \# & $\begin{array}{c}\text { Temp } \\
{ }^{\circ} \mathrm{C}\end{array}$ & $\begin{array}{c}\text { Time } \\
48 \\
\text { Hour }\end{array}$ & $\begin{array}{c}\text { Time } \\
1 / 2 \\
\text { Hour }\end{array}$ & $\begin{array}{c}\text { Time } \\
3 \\
\text { Hour }\end{array}$ & $\begin{array}{l}\text { Sugar } \\
\text { None }\end{array}$ & $\begin{array}{c}\text { Sugar } \\
1 / 2 \mathrm{X}\end{array}$ & $\begin{array}{l}\text { Sugar } \\
1 \mathrm{X}\end{array}$ & Add & $\begin{array}{l}\text { Major } \\
\text { Phase } \\
\text { Desired }\end{array}$ & $\begin{array}{l}\text { Major Phases Identified by X- } \\
\text { Ray Diffraction }\end{array}$ & $\begin{array}{l}\text { Minor Phases Identified by X- } \\
\text { Ray Diffraction }\end{array}$ & $\begin{array}{l}\text { NaTPB, } \\
\text { 3PB, 2PB } \\
\quad \text { (ug/g) }\end{array}$ & $\begin{array}{c}\text { 100-(Heated/Baseline } \mathrm{NO}_{3} \\
\text { (from Table 5) wt } \% * 100) \\
=\% \text { Destroyed }\end{array}$ \\
\hline T48-0 & & & & & & & & 0 & $\mathrm{Na}_{2} \mathrm{CO}_{3}$ & $\begin{array}{c}\mathrm{Na}_{3} \mathrm{H}\left(\mathrm{CO}_{3}\right)_{2}\left(\mathrm{H}_{2} \mathrm{O}\right)_{2}, \mathrm{Na}\left(\mathrm{NO}_{3}\right) \\
\mathrm{NaNO}_{2}, \mathrm{Na}_{2} \mathrm{CO}_{3} \bullet \mathrm{H}_{2} \mathrm{O}\end{array}$ & $\mathrm{Na}_{2} \mathrm{SiO}_{3}, \mathrm{KAl}\left(\mathrm{SO}_{4}\right)_{2}\left(\mathrm{H}_{2} \mathrm{O}\right)_{12}$ & $\begin{array}{l}95,100 \\
<5,<5\end{array}$ & $100-\left((16.3 / 16.3)^{*} 100\right)=0 \%$ \\
\hline T48-1 & 725 & & $\mathrm{X}$ & & $\mathrm{X}$ & & & 0 & $\mathrm{Na}_{2} \mathrm{CO}_{3}$ & $\mathrm{Na}_{2} \mathrm{CO}_{3} \bullet \mathrm{H}_{2} \mathrm{O}, \mathrm{Na}_{2} \mathrm{CO}_{3}$ & $\begin{array}{c}\mathrm{Al}(\mathrm{OH})_{3}(?), \\
\mathrm{Ca}_{8} \mathrm{Al}_{2} \mathrm{Fe}_{2} \mathrm{O}_{12} \mathrm{CO}_{3}(\mathrm{OH})_{2} \bullet 22 \mathrm{H}_{2} \mathrm{O}\end{array}$ & $<5,<5,<5$ & $100-((11.4 / 16.3) * 100)=30.1 \%$ \\
\hline T48-2 & 725 & & & $\mathrm{X}$ & $\bar{X}$ & & & 0 & $\mathrm{Na}_{2} \mathrm{CO}_{3}$ & $\mathrm{Na}_{2} \mathrm{CO}_{3} \bullet \mathrm{H}_{2} \mathrm{O}, \mathrm{Na}_{2} \mathrm{CO}_{3}$ & $\begin{array}{c}\mathrm{Al}(\mathrm{OH})_{3}(?), \\
\mathrm{Ca}_{8} \mathrm{Al}_{2} \mathrm{Fe}_{2} \mathrm{O}_{12} \mathrm{CO}_{3}(\mathrm{OH})_{2} \bullet 22 \mathrm{H}_{2} \mathrm{O}\end{array}$ & $<5,<5,<5$ & $100-\left((15.6 / 16.3)^{*} 100\right)=4.3 \%$ \\
\hline T48-2B & 650 & & & $\mathrm{X}$ & $\mathrm{X}$ & & & 0 & $\mathrm{Na}_{2} \mathrm{CO}_{3}$ & $\mathrm{Na}_{2} \mathrm{CO}_{3} \bullet \mathrm{H}_{2} \mathrm{O}, \mathrm{Na}_{2} \mathrm{CO}_{3}$ & $\begin{array}{c}\mathrm{Al}(\mathrm{OH})_{3}(?), \mathrm{NaNO}_{3} \\
\mathrm{Ca}_{8} \mathrm{Al}_{2} \mathrm{Fe}_{2} \mathrm{O}_{12} \mathrm{CO}_{3}(\mathrm{OH})_{2} \bullet 22 \mathrm{H}_{2} \mathrm{O}\end{array}$ & $<5,<5,<5$ & $100-((12.3 / 16.3) * 100)=24.5 \%$ \\
\hline T48-3 & 725 & & & $\mathrm{X}$ & & $\mathrm{X}$ & & 0 & $\mathrm{Na}_{2} \mathrm{CO}_{3}$ & $\mathrm{Na}_{2} \mathrm{CO}_{3} \bullet \mathrm{H}_{2} \mathrm{O}, \mathrm{Na}_{2} \mathrm{CO}_{3}$ & $\mathrm{Ca}_{8} \mathrm{Al}_{2} \mathrm{Fe}_{2} \mathrm{O}_{12} \mathrm{CO}_{3}(\mathrm{OH})_{2} \bullet 22 \mathrm{H}_{2} \mathrm{O}$ & $<5,<5,<5$ & $100-((0.09 / 16.3) * 100)=99.5 \%$ \\
\hline T48-4 & 725 & & $\mathrm{X}$ & & & & $\mathrm{X}$ & 0 & $\mathrm{Na}_{2} \mathrm{CO}_{3}$ & $\mathrm{Na}_{2} \mathrm{CO}_{3} \bullet \mathrm{H}_{2} \mathrm{O}, \mathrm{Na}_{2} \mathrm{CO}_{3}$ & $\mathrm{Ca}_{2} \mathrm{SiO}_{4}(?), \mathrm{Al}(\mathrm{OH})_{3}(?)$ & $<5,<5,<5$ & $100-\left((0.31 / 16.3)^{*} 100\right)=98.1 \%$ \\
\hline T48-5 & 725 & & & $\mathrm{X}$ & & & $\mathrm{X}$ & 0 & $\mathrm{Na}_{2} \mathrm{CO}_{3}$ & $\mathrm{Na}_{2} \mathrm{CO}_{3} \bullet \mathrm{H}_{2} \mathrm{O}, \mathrm{Na}_{2} \mathrm{CO}_{3}$ & $\begin{array}{c}\mathrm{Ca}_{8} \mathrm{Al}_{2} \mathrm{Fe}_{2} \mathrm{O}_{12} \mathrm{CO}_{3}(\mathrm{OH})_{2} \bullet 22 \mathrm{H}_{2} \mathrm{O} \\
\mathrm{Al}(\mathrm{OH})_{3}(?)\end{array}$ & $<5,<5,<5$ & $100-((0.41 / 16.3) * 100)=97.5 \%$ \\
\hline T48-5B & 650 & & & $\mathrm{X}$ & & & $\mathrm{X}$ & 0 & $\mathrm{Na}_{2} \mathrm{CO}_{3}$ & $\mathrm{Na}_{2} \mathrm{CO}_{3} \bullet \mathrm{H}_{2} \mathrm{O}, \mathrm{Na}_{2} \mathrm{CO}_{3}$ & NONE & $<5,<5,<5$ & $100-\left((0.15 / 16.3)^{*} 100\right)=99.1 \%$ \\
\hline T48-6 & 725 & & $\mathrm{X}$ & & $\mathrm{X}$ & & & $\begin{array}{l}\text { Fine } \\
\mathrm{SiO}_{2}\end{array}$ & $\mathrm{Na}_{4} \mathrm{SiO}_{4}$ & $\begin{array}{c}\mathrm{Na}_{2} \mathrm{CO}_{3}, \mathrm{Na}_{2} \mathrm{CO}_{3} \bullet \mathrm{H}_{2} \mathrm{O} \\
\mathrm{K}_{48.2} \mathrm{Al}_{48.2} \mathrm{Si}_{143.8} \mathrm{O}_{384} \bullet 243 \mathrm{H}_{2} \mathrm{O}\end{array}$ & $\mathrm{Na}_{2} \mathrm{SiO}_{3}$ & $<5,<5,<5$ & $100-\left((10.6 / 16.3)^{*} 100\right)=35.0 \%$ \\
\hline T48-7 & 725 & & & $\mathrm{X}$ & $\mathrm{X}$ & & & $\begin{array}{l}\text { Fine } \\
\mathrm{SiO}_{2}\end{array}$ & $\mathrm{Na}_{4} \mathrm{SiO}_{4}$ & $\begin{array}{c}\mathrm{Na}_{2} \mathrm{CO}_{3}, \mathrm{Na}_{2} \mathrm{SiO}_{3}, \\
\mathrm{Na}_{7.89}\left(\mathrm{AlSiO}_{4}\right)_{6}\left(\mathrm{NO}_{3}\right)_{1.92}\end{array}$ & $\begin{array}{l}\mathrm{Na}_{2} \mathrm{CO}_{3} \bullet \mathrm{H}_{2} \mathrm{O} \\
\mathrm{NaTPB}(?)\end{array}$ & $<5,<5,<5$ & $100-\left((5.98 / 16.3)^{*} 100\right)=63.3 \%$ \\
\hline T48-7B & 650 & & & $\mathrm{X}$ & $\mathrm{X}$ & & & $\begin{array}{l}\text { Fine } \\
\mathrm{SiO}_{2}\end{array}$ & $\mathrm{Na}_{4} \mathrm{SiO}_{4}$ & $\begin{array}{c}\mathrm{Na}_{2} \mathrm{CO}_{3}, \mathrm{Na}_{2} \mathrm{SiO}_{3}, \\
\mathrm{Na}_{7.89}\left(\mathrm{AlSiO}_{4}\right)_{6}\left(\mathrm{NO}_{3}\right)_{1.92}\end{array}$ & $\begin{array}{c}\mathrm{Na}_{2} \mathrm{CO}_{3} \bullet \mathrm{H}_{2} \mathrm{O} \\
\mathrm{K}_{48.2} \mathrm{Al}_{48.2} \mathrm{Si}_{143.8} \mathrm{O}_{384} \bullet 243 \mathrm{H}_{2} \mathrm{O}\end{array}$ & $<5,<5,<5$ & $100-\left((9.55 / 16.3)^{*} 100\right)=41.4 \%$ \\
\hline T48-8 & 725 & & & $\mathrm{X}$ & & $\mathrm{X}$ & & $\begin{array}{l}\text { Fine } \\
\mathrm{SiO}_{2}\end{array}$ & $\mathrm{Na}_{4} \mathrm{SiO}_{4}$ & $\begin{array}{c}\mathrm{Na}_{2} \mathrm{CO}_{3}, \mathrm{Na}_{2} \mathrm{CO}_{3} \bullet \mathrm{H}_{2} \mathrm{O} \\
\mathrm{Na}_{2} \mathrm{SiO}_{3}, \\
\end{array}$ & $\begin{array}{c}\mathrm{KAlSiO}_{4} \\
\mathrm{~K}_{48.2} \mathrm{Al}_{48.2} \mathrm{Si}_{143.8} \mathrm{O}_{384} \bullet 243 \mathrm{H}_{2} \mathrm{O}\end{array}$ & $<5,<5,<5$ & $100-\left((0.78 / 16.3)^{*} 100\right)=95.2 \%$ \\
\hline T48-9 & 725 & & $\mathrm{X}$ & & & & $\mathrm{X}$ & $\begin{array}{l}\text { Fine } \\
\mathrm{SiO}_{2}\end{array}$ & $\mathrm{Na}_{4} \mathrm{SiO}_{4}$ & $\begin{array}{c}\mathrm{Na}_{2} \mathrm{CO}_{3}, \mathrm{Na}_{2} \mathrm{CO}_{3} \bullet \mathrm{H}_{2} \mathrm{O}, \mathrm{Na}_{2} \mathrm{SiO}_{3}, \\
\mathrm{~K}_{48.2} \mathrm{Al}_{48.2} \mathrm{Si}_{143.8} \mathrm{O}_{384} \bullet 243 \mathrm{H}_{2} \mathrm{O}\end{array}$ & $\mathrm{KAlSiO}_{4}$ & $<5,<5,<5$ & $100-((1.18 / 16.3) * 100)=92.8 \%$ \\
\hline T48-10 & 725 & & & $\mathrm{X}$ & & & $\mathrm{X}$ & $\begin{array}{l}\text { Fine } \\
\mathrm{SiO}_{2}\end{array}$ & $\mathrm{Na}_{4} \mathrm{SiO}_{4}$ & $\begin{array}{c}\mathrm{Na}_{2} \mathrm{CO}_{3} \bullet \mathrm{H}_{2} \mathrm{O}, \mathrm{Na}_{2} \mathrm{SiO}_{3} \\
\mathrm{~K}_{48.2} \mathrm{Al}_{48.2} \mathrm{Si}_{143.8} \mathrm{O}_{384} \bullet 243 \mathrm{H}_{2} \mathrm{O}\end{array}$ & NONE & $<5,<5,<5$ & $100-\left((0.22 / 16.3)^{*} 100\right)=98.7 \%$ \\
\hline T48-10B & 650 & & & $\mathrm{X}$ & & & $\mathrm{X}$ & $\begin{array}{l}\text { Fine } \\
\mathrm{SiO}_{2}\end{array}$ & $\mathrm{Na}_{4} \mathrm{SiO}_{4}$ & $\begin{array}{c}\mathrm{Na}_{2} \mathrm{CO}_{3}, \mathrm{Na}_{2} \mathrm{CO}_{3} \bullet \mathrm{H}_{2} \mathrm{O} \\
\mathrm{Na}_{2} \mathrm{SiO}_{3} \\
\mathrm{~K}_{48.2} \mathrm{Al}_{48.2} \mathrm{Si}_{143.8} \mathrm{O}_{384} \bullet 243 \mathrm{H}_{2} \mathrm{O}\end{array}$ & $\mathrm{KAlSiO}_{4}$ & $<5,<5,<5$ & $100-\left((0.96 / 16.3)^{*} 100\right)=94.1 \%$ \\
\hline $\begin{array}{l}\text { T48-11 } \\
(\text { see } 6)\end{array}$ & 725 & $\mathrm{X}$ & & $\mathrm{X}$ & $\mathrm{X}$ & & & $\begin{array}{l}\text { Fine } \\
\mathrm{SiO}_{2}\end{array}$ & $\mathrm{Na}_{4} \mathrm{SiO}_{4}$ & $\begin{array}{c}\mathrm{Na}_{2} \mathrm{SiO}_{3,} \\
\mathrm{~K}_{48.2} \mathrm{Al}_{48.2} \mathrm{Si}_{143.8} \mathrm{O}_{384} \bullet 243 \mathrm{H}_{2} \mathrm{O}\end{array}$ & $\mathrm{Na}_{2} \mathrm{CO}_{3} \bullet \mathrm{H}_{2} \mathrm{O}$ & $<5,<5,<5$ & $100-((0.03 / 16.3) * 100)=99.8 \%$ \\
\hline $\begin{array}{l}\mathrm{T} 48-12 \\
(\mathrm{see} 10)\end{array}$ & 725 & $\mathrm{X}$ & & $\mathrm{X}$ & & & $\mathrm{X}$ & $\begin{array}{l}\text { Fine } \\
\mathrm{SiO}_{2}\end{array}$ & $\mathrm{Na}_{4} \mathrm{SiO}_{4}$ & $\begin{array}{c}\mathrm{Na}_{2} \mathrm{CO}_{3} \bullet \mathrm{H}_{2} \mathrm{O} \\
\mathrm{Na}_{2} \mathrm{SiO}_{3}\end{array}$ & NONE & $<5,<5,<5$ & $100-\left((0.19 / 16.3)^{*} 100\right)=98.8 \%$ \\
\hline $\begin{array}{l}\mathrm{T} 48-13 \\
\text { (see 5B) }\end{array}$ & 650 & $\mathrm{X}$ & & & & & $\mathrm{X}$ & 0 & $\mathrm{Na}_{2} \mathrm{CO}_{3}$ & $\mathrm{Na}_{2} \mathrm{CO}_{3} \bullet \mathrm{H}_{2} \mathrm{O}, \mathrm{Na}_{2} \mathrm{CO}_{3}$ & NONE & $<5,<5,<5$ & $100-\left((0.16 / 16.3)^{*} 100\right)=99.0 \%$ \\
\hline $\mathrm{T} 48-14$ & 725 & $\mathrm{X}$ & & & & & $\mathrm{X}$ & $\begin{array}{l}\text { Fine } \\
\mathrm{SiO}_{2} \\
\end{array}$ & $\begin{array}{l}\mathrm{Na}_{4} \mathrm{SiO}_{4} \\
\text { faujesite }\end{array}$ & $\mathrm{Na}_{2} \mathrm{CO}_{3} \bullet \mathrm{H}_{2} \mathrm{O}, \mathrm{Na}_{2} \mathrm{SiO}_{3}$ & $\mathrm{Na}\left(\mathrm{NO}_{3}\right)$ & $<5,<5,<5$ & $100-\left((0.25 / 16.3)^{*} 100\right)=98.5 \%$ \\
\hline $\mathrm{T} 48-15$ & 725 & $\bar{X}$ & & & & & $\mathrm{X}$ & $\begin{array}{l}\text { Fine } \\
\mathrm{SiO}_{2}\end{array}$ & $\begin{array}{l}\mathrm{Na}_{2} \mathrm{SiO}_{3} \\
\text { faujesite }\end{array}$ & $\mathrm{Na}_{2} \mathrm{CO}_{3} \bullet \mathrm{H}_{2} \mathrm{O}, \mathrm{Na}_{2} \mathrm{Si}_{2} \mathrm{O}_{5}$ & $\begin{array}{c}\mathrm{Na}_{2} \mathrm{SiO}_{3}, \mathrm{Na}\left(\mathrm{NO}_{3}\right) \\
\mathrm{K}_{48.2} \mathrm{Al}_{48.2} \mathrm{Si}_{143.8} \mathrm{O}_{384} \bullet 243 \mathrm{H}_{2} \mathrm{O}\end{array}$ & $<5,<5,<5$ & $100-\left((0.10 / 16.3)^{*} 100\right)=99.4 \%$ \\
\hline
\end{tabular}


WSRC-TR-2003-00352, Rev. 0

\subsection{QUALITY ASSURANCE}

All the data reported in this study were developed under the quality assurance given in technical task plan WSRC-RP-2003-00396 [18]. The research program and task plan were developed to address TTR-HLE-TTR-2003-102. The data are recorded in notebook WSRC-NB-2003-00140.

\subsection{RESULTS AND DISCUSSION}

\subsection{Static Vs. Dynamic Tests and Reaction Residence Time}

Due to the static nature of the environment inside the crucibles compared to the active environment of a steam reformer, most of the crucible FBSR samples were stratified and thus inhomogeneous (see photos in Appendix A). Reaction times of 48 hours produced the most homogeneous, least stratified, and best-reacted, samples. Samples were ground and mixed to homogenize them before any analyses were performed.

\subsection{Baseline Testing}

A sample (T48-0) was tested as a baseline. The T48-0 sample was carbonated, anitfoam and $\mathrm{Fe}\left(\mathrm{NO}_{3}\right)_{3} \bullet 9 \mathrm{H}_{2} \mathrm{O}$ were added, and the sample was dried at $60^{\circ} \mathrm{C}$. This sample was analyzed for TPB by HPLC, for anions, for TC, TIC, TOC and REDOX as a baseline case (see Table 4, Table 5 and Table 6). These analyses demonstrated that there was 95,100 ug/g of TPB (Table 4) present in the samples after the carbonation and drying steps. The presence of the TPB was also confirmed by the measurement of TOC in sample T48-0 (Table 6) which showed that 19,500 ug/g of organic carbon that was present in the sample. Either the TPB or the anitfoam (an organic) may have reacted with the $\mathrm{Fe}\left(\mathrm{NO}_{3}\right)_{3} \bullet 9 \mathrm{H}_{2} \mathrm{O}$ because an all $\mathrm{Fe}^{+3}$ dried solution should have had a REDOX measurement of $\sim 0$ and $\mathrm{T} 48-0$ had a measured $\mathrm{Fe}^{+2} / \Sigma \mathrm{Fe}$ of 0.44 (Table 6 ) indicating that a considerable amount of $\mathrm{Fe}^{+2}$ was present or that the organics interfered with the REDOX measurement. Anion analysis of the base case indicated $<100 \mathrm{ug} / \mathrm{g}$ of $\mathrm{NO}_{2}$ and a $\mathrm{NO}_{3}$ content of $163,000 \mathrm{ug} / \mathrm{g}$ or $16.3 \mathrm{wt} \%$ (Table 5). This number was used with the rest of the measured $\mathrm{NO}_{3}$ data in Table 5 to calculate the $\mathrm{NO}_{3}$ destruction values given in Table 4.

\subsection{Tetraphenylborate Destruction}

Samples were tested at two different temperatures, $650^{\circ} \mathrm{C}$ and $725^{\circ} \mathrm{C}$ (Table 4). Tetraphenylborate (TPB) was completely destroyed in all the samples tested, e.g. the $\mathrm{TPB}, 2 \mathrm{~PB}$ and $3 \mathrm{~PB}$ were all $<5 \mathrm{ug} / \mathrm{g}$ indicating that the thermal treatment destroyed all the $\mathrm{TPB}$ and its derivatives. This was confirmed by the TOC analyses for all the samples 
thermally treated, $<100 \mathrm{ug} / \mathrm{g}$ of TOC (Table 6). This indicates that FBSR is a viable technology for destruction of the organics in Tank $48 \mathrm{H}$.

\subsection{Carbonate FBSR Products}

For all of the FBSR simulated samples in which the desired product was $\mathrm{Na}_{2} \mathrm{CO}_{3}$ (samples T48-1 through T48-5B and T48-13), analysis by XRD indicated that a mixture of $\mathrm{Na}_{2} \mathrm{CO}_{3} \bullet \mathrm{H}_{2} \mathrm{O}$ and $\mathrm{Na}_{2} \mathrm{CO}_{3}$ was formed regardless of temperature and residence time in the furnace (Table 4). However, for the T48-13 sample that was heated at $650^{\circ} \mathrm{C}$ for 48 hours, the XRD analysis indicated no minor constituents. This meant that the minor constituents that had appeared in the same sample reacted for only 3 hours were due to incomplete reaction. Test T48-5B or T48-13 appeared optimal for making the $\mathrm{Na}_{2} \mathrm{CO}_{3}$ FBSR product at $650^{\circ} \mathrm{C}, 1 \mathrm{X}$ stoichiometric sugar and 3-48 hour residence time as no minor phases were identified as incomplete reactants. Only the two primary phases $\mathrm{Na}_{2} \mathrm{CO}_{3}$ and $\mathrm{Na}_{2} \mathrm{CO}_{3} \bullet \mathrm{H}_{2} \mathrm{O}$ were present in the T48-5 and T48-13 samples.

\subsection{Silicate FBSR Products}

In the current study $\mathrm{Na}_{4} \mathrm{SiO}_{4}$ was chosen as the FBSR phase of choice because it melts at $\sim 1120^{\circ} \mathrm{C}$ and can only coexist with a liquid phase down to temperatures as low as $1040^{\circ} \mathrm{C}$. This choice was made to limit any potential liquid phase in the steam reformer that might cause bed agglomeration. $\mathrm{Na}_{2} \mathrm{SiO}_{3}$ may be acceptable for use as feed in the DWPF as its melting temperature is $\sim 1080^{\circ} \mathrm{C}$ but it can coexist with a $\mathrm{Na}_{2} \mathrm{O}-\mathrm{SiO}_{2}$ liquid phase that melts as low as $825^{\circ} \mathrm{C}$ and may cause bed agglomeration. Sodium silicate $\left(\mathrm{Na}_{2} \mathrm{SiO}_{3}\right)$ was the silicate FBSR product phase made by $\mathrm{THOR}^{\mathrm{sm}}$ in their pilot scale studies (Table 1) with Hanford's high $\mathrm{Na}^{+}$containing Low Activity Waste (LAW).

For all of the simulated FBSR samples in which the desired product was $\mathrm{Na}_{4} \mathrm{SiO}_{4}$ with a $\mathrm{Na}_{2} \mathrm{O}: \mathrm{SiO}_{2}$ ratio of 2:1 (T48-6 through T48-12), a potassium aluminosilicate zeolite phase known as faujasite $\left(\mathrm{K}_{48.2} \mathrm{Al}_{48.2} \mathrm{Si}_{143.8} \mathrm{O}_{384} \bullet 243 \mathrm{H}_{2} \mathrm{O}\right)$ was identified by XRD and a sodium silicate of a 1:1 $\mathrm{Na}_{2} \mathrm{O}: \mathrm{SiO}_{2}$ stoichiometry had formed (Table 4). Excess $\mathrm{SiO}_{2}$ does not appear on the XRD pattern since the precipitated $\mathrm{SiO}_{2}$ that was added to the sample is amorphous and will not give an XRD signal. It was apparent that the faujesite was consuming some of the $\mathrm{SiO}_{2}$ that was meant to form the $2: 1$ sodium silicate phase.

Subsequent testing (T48-14) was designed to compensate for the silica being consumed by the faujesite. X-ray Diffraction analysis (Table 4) indicated that the major phases in the T48-14 sample after a 48 hour residence time were indeed the faujasite and the 1:1 $\mathrm{Na}_{2} \mathrm{O}: \mathrm{SiO}_{2}$ phase. Another test (T48-15) that was designed to make the sodium silicate with a 1:1 stoichiometry of $\mathrm{Na}_{2} \mathrm{O}: \mathrm{SiO}_{2}$, gave an XRD pattern for yet another sodium silicate with a $\mathrm{Na}_{2} \mathrm{O}: \mathrm{SiO}_{2}$ stoichiometry of 1:2 $\left(\mathrm{Na}_{2} \mathrm{Si}_{2} \mathrm{O}_{5}\right)$. This sample also had unreacted $\mathrm{Na}_{2} \mathrm{CO}_{3}$ present and presumably XRD amorphous $\mathrm{SiO}_{2}$.

Analysis of all the silicate FBSR products was performed to determine if the correct ratios of $\mathrm{Na}_{2} \mathrm{O}: \mathrm{SiO}_{2}$ had been added during experimentation. These analyses indicated that some of the $\mathrm{Na}_{2} \mathrm{O}: \mathrm{SiO}_{2}$ ratios measured (Table 5) were biased low by $\sim 20 \%$. This 


\section{WSRC-TR-2003-00352, Rev. 0}

may be because the precipitated silica contains absorbed water that was not factored into the batching calculation.

Even at 48 hours residence time (samples T48-12, T48-14, and T48-15) not all of the sodium carbonates present in the silicate FBSR samples converted to sodium silicate. The XRD spectra indicates the presence of carbonate phases and the high concentrations of TIC in Table 6 indicate large quantities of unreacted carbonate. Thus, incomplete reaction of the carbonates and silica is occurring at reaction temperatures of $650-725^{\circ} \mathrm{C}$ even with finely precipitated silica. Higher temperatures and the presence of excess $\mathrm{SiO}_{2}$ may be necessary to force the final conversion of the carbonates to silicates under FBSR conditions.

In summary, if a silicate FBSR phase was desired, a silica FBSR phase was the major phase formed with carbonate and faujesite always present. Although the exact $\mathrm{Na}_{2} \mathrm{O}: \mathrm{SiO}_{2}$ ratio of the desired FBSR silicate phase was never achieved due to incomplete reaction and silica deficient starting mixtures, this would not hinder the usage of any sodium silicate FBSR material made from Tank 48H slurry in DWPF. Achieving the desired $\mathrm{Na}_{2} \mathrm{O}: \mathrm{SiO}_{2}$ ratio for silicate based FBSR products needs further optimization.

\subsection{Nitrate and Sugar Destruction}

In the sample test matrix (Table 4), samples with the designation of B indicate comparison of tests at the two different reaction temperatures. These were designed into the test matrix to test the optimum $\mathrm{NO}_{3}$ destruction at the various temperatures, e.g. optimize the WGSR. Hence samples T48-2B, 5B, 7B and $10 \mathrm{~B}$ were tested at $650^{\circ} \mathrm{C}$ while samples T48-2, 5, 7, and 10 were tested at $725^{\circ} \mathrm{C}$.

For two of the pairs of samples tested at the different temperatures, T48-2 and 2B and T48-5 and 5B, the desired FBSR product was $\mathrm{Na}_{2} \mathrm{CO}_{3}$. Samples T48-2 and T48-2B had no sugar and samples T48-5 and T48-5B had 1X stoichiometric sugar. Comparison of the XRD spectra of the two tests without sugar demonstrates that the FBSR products in absence of sugar includes undecomposed $\mathrm{NaNO}_{3}$ which indicates that nitrate destruction is incomplete when sugar is absent at $650^{\circ} \mathrm{C}$ and $725^{\circ} \mathrm{C}$, e.g. when sugar is absent there is no CO to optimize the WGSR. This is confirmed by the nitrate analyses in Table 5 and the nitrate destruction percentages given in Table 4 which indicate that nitrate was not destroyed at either temperature for samples T48-2 and T48-2B. For the sample pair T485 and T48-5B sucrose was present at $1 \mathrm{X}$ stoichiometry. These samples had $99.1 \%$ and $97.5 \% \mathrm{NO}_{3}$ destruction at the $650^{\circ} \mathrm{C}$ and $725^{\circ} \mathrm{C}$ temperatures respectively (Table 4). This indicates that the WGSR may be better optimized at $650^{\circ} \mathrm{C}$ than at the $725^{\circ} \mathrm{C}$. Likewise, the TOC analyses in Table 6 indicate no residual TOC in the form of sucrose in the samples and the XRD spectra did not indicate any residual $\mathrm{NaNO}_{3}$ (Table 4).

For two of the pairs of samples tested at the different temperatures, T48-7 and 7B and T48-10 and 10B, the desired FBSR product was a sodium silicate. Sample T48-7B had no sugar and Sample T48-10B had 1X stoichiometric sugar. Comparison of the XRD spectra of the two tests without did not show any undecomposed $\mathrm{NaNO}_{3}$ but the nitrate 
analyses shown in Table 5 indicate that considerable $\mathrm{NO}_{3}$ remains in the samples without sugar. The nitrate destruction percentages given in Table 4 for these samples indicate that nitrate was only partially destroyed at either temperature for samples T48-7 and T48$7 \mathrm{~B}$, e.g. $41.4 \%$ and $63.3 \%$ at the lower and higher temperatures, respectively. For the sample pair T48-10 and T48-10B sucrose was present at $1 \mathrm{X}$ stoichiometry. These samples had $98.7 \%$ and $94.1 \% \mathrm{NO}_{3}$ destruction at the $650^{\circ} \mathrm{C}$ and $725^{\circ} \mathrm{C}$ temperatures respectively (Table 4). This again indicates that the WGSR may be better optimized at $650^{\circ} \mathrm{C}$ than at the $725^{\circ} \mathrm{C}$. Likewise, the TOC analyses in Table 6 indicate no residual TOC in the form of sucrose in the samples and the XRD spectra did not indicate any residual $\mathrm{NaNO}_{3}$ (Table 4).

The small amount of TOC measured in all the samples (Table 6) indicates that at $1 / 2$ to $1 \mathrm{X}$ sugar stoichiometry that most of the sugar and char are consumed during denitration and that the FBSR product should not be overly reducing and thus compatible with DWPF processing of the FBSR product.

\subsection{Particle Agglomeration}

No adherence of the silicate or carbonate phases onto the $\mathrm{Al}_{2} \mathrm{O}_{3}$ crucibles was noted in any of the tests. Therefore, if the FBSR bed media used is $\mathrm{Al}_{2} \mathrm{O}_{3}$ there should be little sticking and particle agglomeration regardless of whether the FBSR product is carbonate or silicate. This also indicates that the $\mathrm{Na}_{2} \mathrm{SiO}_{3}$ phase that was produced most often as an FBSR product in this study (see the XRD identifications in Table 4) appears to be an acceptable FBSR product phase. This was confirmed by the pilot scale testing completed by THOR $^{\mathrm{sm}}$ (Table 1) on the Hanford AN-107 simulant.

\subsection{FBSR Product Melt Temperatures}

FBSR product samples T48-5B $\left(\mathrm{Na}_{2} \mathrm{CO}_{3}\right.$ made at $\left.650^{\circ} \mathrm{C}\right), \mathrm{T} 48-10$ (mixed $\mathrm{Na}_{2} \mathrm{CO}_{3}$ and $\mathrm{Na}_{2} \mathrm{SiO}_{3}$ and faujesite), and $\mathrm{T} 48-11\left(\mathrm{Na}_{2} \mathrm{SiO}_{3}\right.$ and faujesite) were measured by Differential Thermal Analysis (DTA) to determine their melting temperature. The melt temperatures were $980^{\circ} \mathrm{C}, 1022^{\circ} \mathrm{C}$, and $1049^{\circ} \mathrm{C}$, respectively. These melt temperatures are all compatible with melting of these phases in the DWPF although the presence of carbonate on pre-melter processing in the Slurry Receipt Adjustment Tank (SRAT) and alteration of the DWPF frit composition to accommodate these species is still necessary. 
WSRC-TR-2003-00352, Rev. 0

Table 5. Analysis of Anions and Cations in Tank 48H Simulated FBSR Products

\begin{tabular}{|c|c|c|c|c|c|c|c|c|c|}
\hline Test \# & $\begin{array}{c}\text { ML Lab } \\
\text { ID } \\
\text { Anions/ } \\
\text { Cations }\end{array}$ & $\begin{array}{c}\mathrm{NO}_{2} \\
\text { (ug/g) }\end{array}$ & $\begin{array}{c}\mathrm{NO}_{3} \\
(\mathrm{ug} / \mathrm{g})\end{array}$ & $\begin{array}{c}\mathrm{PO}_{4} \\
(\mathrm{ug} / \mathrm{g})\end{array}$ & $\begin{array}{c}\mathrm{SO}_{4} \\
(\mathrm{ug} / \mathrm{g})\end{array}$ & $\begin{array}{c}\mathbf{K}_{2} \mathbf{O} \\
(w t \%)\end{array}$ & $\begin{array}{l}\mathrm{Na}_{2} \mathrm{O} \\
(\mathrm{wt} \%)\end{array}$ & $\begin{array}{c}\mathrm{SiO}_{2} \\
(\mathrm{wt} \%)\end{array}$ & $\begin{array}{l}\text { Alkali } \\
/ \mathrm{SiO}_{2}\end{array}$ \\
\hline T48-0 & 03-0968 & $<100$ & 163000 & 2550 & 3000 & $\mathrm{~N} / \mathrm{A}$ & $\mathrm{N} / \mathrm{A}$ & $\mathrm{N} / \mathrm{A}$ & N/A \\
\hline T48-1 & 03-0914 & $<100$ & 114000 & 1740 & 3750 & $\mathrm{~N} / \mathrm{A}$ & $\mathrm{N} / \mathrm{A}$ & $\mathrm{N} / \mathrm{A}$ & N/A \\
\hline T48-2 & 03-01915 & $<100$ & 156000 & 1690 & 3850 & $\mathrm{~N} / \mathrm{A}$ & $\mathrm{N} / \mathrm{A}$ & $\mathrm{N} / \mathrm{A}$ & $\mathrm{N} / \mathrm{A}$ \\
\hline T48-2B & 03-01916 & $<100$ & 123000 & 2350 & 4500 & $\mathrm{~N} / \mathrm{A}$ & $\mathrm{N} / \mathrm{A}$ & $\mathrm{N} / \mathrm{A}$ & N/A \\
\hline T48-3 & 03-01917 & $<100$ & 947 & $<100$ & 4380 & $\mathrm{~N} / \mathrm{A}$ & $\mathrm{N} / \mathrm{A}$ & $\mathrm{N} / \mathrm{A}$ & N/A \\
\hline T48-4 & 03-01918 & $<100$ & 3080 & 2980 & 4500 & $\mathrm{~N} / \mathrm{A}$ & $\mathrm{N} / \mathrm{A}$ & $\mathrm{N} / \mathrm{A}$ & N/A \\
\hline T48-5 & 03-01919 & $<100$ & 4060 & 1970 & 4080 & N/A & N/A & $\mathrm{N} / \mathrm{A}$ & N/A \\
\hline T48-5B & 03-01920 & $<100$ & 1480 & 2730 & 4700 & $\mathrm{~N} / \mathrm{A}$ & $\mathrm{N} / \mathrm{A}$ & $\mathrm{N} / \mathrm{A}$ & N/A \\
\hline T48-6 & $\begin{array}{c}03-01921 \\
03-0921\end{array}$ & $<100$ & 106000 & 2240 & 3980 & 1.46 & 40.44 & 24.82 & 1.69 \\
\hline T48-7 & $\begin{array}{c}03-01922 \\
03-0922 \\
\end{array}$ & $<100$ & 59800 & 2010 & 4180 & 1.63 & 42.60 & 24.82 & 1.78 \\
\hline T48-7B & $\begin{array}{c}03-01923 \\
03-0923\end{array}$ & $<100$ & 95500 & 2370 & 3970 & 1.59 & 42.87 & 23.96 & 1.86 \\
\hline T48-8 & $\begin{array}{c}03-01924 \\
03-0924\end{array}$ & $<100$ & 779 & 2600 & 3900 & 1.66 & 43.67 & 23.75 & 1.91 \\
\hline T48-9 & $\begin{array}{c}03-01925 \\
03-0925\end{array}$ & $<100$ & 11800 & 2920 & 4040 & 1.87 & 42.60 & 24.17 & 1.84 \\
\hline T48-10 & $\begin{array}{c}03-01926 \\
03-0926\end{array}$ & $<100$ & 2210 & 3550 & 4350 & 1.83 & 47.72 & 23.53 & 2.11 \\
\hline $\begin{array}{l}\text { T48- } \\
10 \mathrm{~B}\end{array}$ & $\begin{array}{c}03-01927 \\
03-0927\end{array}$ & $<100$ & 9640 & 3120 & 3990 & 1.64 & 44.89 & 20.86 & 2.23 \\
\hline T48-11 & $\begin{array}{c}03-01928 \\
03-0928\end{array}$ & $<100$ & 332 & 3880 & 4660 & 2.35 & 45.83 & 27.38 & 1.76 \\
\hline T48-12 & $\begin{array}{c}03-01929 \\
03-0929 \\
\end{array}$ & $<100$ & 1930 & 1930 & 4190 & 2.10 & 47.05 & 23.96 & 2.05 \\
\hline T48-13 & $03-1020$ & $<100$ & 1640 & 3380 & 4410 & $\mathrm{~N} / \mathrm{A}$ & N/A & $\mathrm{N} / \mathrm{A}$ & N/A \\
\hline T48-14 & $\begin{array}{l}03-1016 \\
03-1016\end{array}$ & $<100$ & 2450 & 3470 & 4430 & 1.73 & 49.07 & 28.67 & 1.77 \\
\hline T48-15 & $\begin{array}{l}03-1017 \\
03-1017\end{array}$ & $<100$ & 1020 & 2710 & 3370 & 1.66 & 39.63 & 47.92 & 0.86 \\
\hline
\end{tabular}


Table 6. Measured REDOX, Total Carbon, Total Inorganic Carbon, and Total Organic Carbon for Simulated Tank 48H FBSR Products

\begin{tabular}{|c|c|c|c|c|c|c|c|}
\hline Test \# & $\begin{array}{c}\text { ML Lab } \\
\text { ID }\end{array}$ & $\mathbf{F e}^{+\mathbf{2}} / \mathbf{\Sigma F e}$ & $\begin{array}{c}\text { Calc- } \\
\mathbf{l o g} f_{O_{2}}\end{array}$ & $\begin{array}{c}\text { ADS Lab } \\
\text { ID }\end{array}$ & $\begin{array}{c}\text { TC } \\
(\mathbf{u g} / \mathbf{g})\end{array}$ & $\begin{array}{c}\text { TIC } \\
(\mathbf{u g} / \mathbf{g})\end{array}$ & $\begin{array}{c}\text { TOC } \\
(\mathbf{u g} / \mathbf{g})\end{array}$ \\
\hline $\mathrm{T} 48-0$ & $03-0968$ & 0.44 & -7.36 & 300197937 & 61900 & 42400 & 19500 \\
\hline $\mathrm{T} 48-1$ & $03-01914$ & 0.70 & -9.78 & 300197938 & 65300 & 65300 & $<100$ \\
\hline $\mathrm{T} 48-2$ & $03-01915$ & 0.67 & -9.50 & 300197939 & 66200 & 66200 & $<100$ \\
\hline $\mathrm{T} 48-2 \mathrm{~B}$ & $03-01916$ & 0.74 & -10.14 & 300197940 & 60000 & 60000 & $<100$ \\
\hline $\mathrm{T} 48-3$ & $03-01917$ & 0.83 & -10.96 & 300197941 & 80300 & 80300 & $<100$ \\
\hline $\mathrm{T} 48-4$ & $03-01918$ & 0.73 & -10.05 & 300197942 & 78300 & 78300 & $<100$ \\
\hline $\mathrm{T} 48-5$ & $03-01919$ & 0.62 & -9.05 & 300197943 & 70500 & 70500 & $<100$ \\
\hline $\mathrm{T} 48-5 \mathrm{~B}$ & $03-01920$ & 0.86 & -11.23 & 300197944 & 84000 & 84000 & $<100$ \\
\hline $\mathrm{T} 48-6$ & $03-01921$ & 0.77 & -10.41 & 300197945 & 35300 & 35300 & $<100$ \\
\hline $\mathrm{T} 48-7$ & $03-01922$ & 0.90 & -11.59 & 300197946 & 34900 & 34900 & $<100$ \\
\hline $\mathrm{T} 48-7 \mathrm{~B}$ & $03-01923$ & 0.85 & -11.14 & 300197947 & 36200 & 36200 & $<100$ \\
\hline $\mathrm{T} 48-8$ & $03-01924$ & 0.20 & -5.24 & 300197948 & 43100 & 43100 & $<100$ \\
\hline $\mathrm{T} 48-9$ & $03-01925$ & 0.75 & -10.23 & 300197949 & 46800 & 46800 & $<100$ \\
\hline $\mathrm{T} 48-10$ & $03-01926$ & 0.80 & -10.68 & 300197950 & 50900 & 50900 & $<100$ \\
\hline $\mathrm{T} 48-10 \mathrm{~B}$ & $03-01927$ & 0.78 & -10.50 & 300197951 & 50800 & 50800 & $<100$ \\
\hline $\mathrm{T} 48-11$ & $03-01928$ & 0.21 & -5.33 & 300197952 & 50100 & 50100 & $<100$ \\
\hline $\mathrm{T} 48-12$ & $03-01929$ & 0.78 & -10.50 & 300197953 & 42200 & 42200 & $<100$ \\
\hline $\mathrm{T} 48-13$ & $03-1020$ & 0.37 & -6.78 & 300197954 & 41200 & 41200 & $<100$ \\
\hline $\mathrm{T} 48-14$ & $03-1016$ & 0.79 & -10.59 & 300197955 & 37900 & 37900 & $<100$ \\
\hline $\mathrm{T} 48-15$ & $03-1017$ & 0.60 & -8.87 & 300197956 & 19100 & 19100 & $<100$ \\
\hline
\end{tabular}

\subsection{REDOX Measurements and the Water Gas Shift Reaction (WGSR)}

Although the FBSR product is not borosilicate glass it is a mixture of oxide species. Therefore, the Electro-Motive Force (EMF) REDOX series developed for DWPF glasses, as illustrated in Figure 3, should approximate the REDOX of the FBSR product, et al.[19]. This ordering of REDOX couples in oxygen fugacity-REDOX ratio space (Figure 3 ) defines an electrochemical series in terms of the ease of reduction of particular multivalent ions [19]. Using Figure 3, the measured iron REDOX and total iron ratios from Table 6 for the FBSR product can be used to approximate both the oxygen fugacity (availability of oxygen) in the crucible tests and the relative partial pressures of log $\log p_{\mathrm{H}_{2} \mathrm{O}} / p_{\mathrm{H}_{2}}$ and $\log p_{\mathrm{CO}_{2}} / p_{\mathrm{CO}}$ at the reaction temperature which are the partial pressures of the two half reactions for the WGSR given in Equation 3.

The ratio of the $\mathrm{Fe}^{+2}$ to the total iron is indicated across the top of Schreiber's REDOX series (Figure 3). The relation between the $\mathrm{Fe}^{+2} / \Sigma \mathrm{Fe}$ and the $\log f_{\mathrm{O}_{2}}$ is quantified from this graphical description at $\sim 5 \mathrm{wt} \%$ total iron by the following relationship:

Equation 6

$$
-\log f_{O_{2}}(E M F)=-3.42-9.08 *\left(\frac{F e^{+2}}{\Sigma F e}\right)
$$


By substituting the measured $\left(\frac{F e^{+2}}{\Sigma F e}\right)$ ratio for all the glasses in "Model Data" into Equation 6, one can then determine the $f_{\mathrm{O}_{2}}$ conditions achieved in the FBSR crucible studies.

The average REDOX ratio for the $15 \mathrm{FBSR}$ reactions at $725^{\circ} \mathrm{C}$ are $-\log f_{\mathrm{O}_{2}}=9.69$ (or $\left.\log f_{\mathrm{O}_{2}}=-9.69\right)$ while the average $-\log f_{\mathrm{O}_{2}}$ values for the $4 \mathrm{FBSR}$ reactions at $650^{\circ} \mathrm{C}$ are 10.75 (or $\log f_{\mathrm{O}_{2}}=-10.75$ ). These negative $\log f_{\mathrm{O}_{2}}$ values mean that no oxygen was present during the FBSR reactions.

This can also be expressed as $\log p_{\mathrm{H}_{2} \mathrm{O}} / p_{\mathrm{H}_{2}}$ or $\log p_{\mathrm{CO}_{2}} / p_{\mathrm{CO}}$ because of the thermodynamic equilibrium

and

$$
2 \mathrm{H}_{2} \mathrm{O} \uparrow \rightarrow 2 \mathrm{H}_{2} \uparrow+\mathrm{O}_{2} \uparrow
$$

$$
2 \mathrm{CO}_{2} \uparrow \rightarrow 2 \mathrm{CO} \uparrow+\mathrm{O}_{2} \uparrow
$$

Published correlations [20] between - $\log f_{\mathrm{O}_{2}}$, temperature, and $\log p_{\mathrm{H}_{2} \mathrm{O}} / p_{\mathrm{H}_{2}}$ allows the $\log p_{\mathrm{H}_{2} \mathrm{O}} / p_{\mathrm{H}_{2}}$ in the FBSR crucible studies at $725^{\circ} \mathrm{C}$ to be estimated as between $+5.5-6$ while the FBSR crucible studies at $650^{\circ} \mathrm{C}$ experienced a $\log p_{\mathrm{H}_{2} \mathrm{O}} / p_{\mathrm{H}_{2}}$ in the range of +5 . These positive values mean that the $\log p_{\mathrm{H}_{2} \mathrm{O}} / p_{\mathrm{H}_{2}}$ values are high as they should be to promote the WGSR.

Published correlations [20] between $-\log f_{\mathrm{O}_{2}}$, temperature, and $\log p_{\mathrm{CO}_{2}} / p_{\mathrm{CO}}$ allows the $\log p_{\mathrm{CO}_{2}} / p_{\mathrm{CO}}$ in the FBSR crucible studies at $725^{\circ} \mathrm{C}$ to be estimated at $\sim+5.5$ while the FBSR crucible studies at $650^{\circ} \mathrm{C}$ experienced a $\log p_{\mathrm{CO}_{2}} / p_{\mathrm{CO}}$ in the range of $\sim+4.5-5$. These positive values, which match the $\log p_{\mathrm{H}_{2} \mathrm{O}} / p_{\mathrm{H}_{2}}$ values reported above, mean that the $\log p_{\mathrm{CO}_{2}} / p_{\mathrm{CO}}$ values are high as they should be to promote the WGSR.

The use of the REDOX measurements and approximations, therefore, confirms that highly deoxygenated conditions were achieved and that the crucible studies simulated the WGSR conditions. 
WSRC-TR-2003-00352, Rev. 0

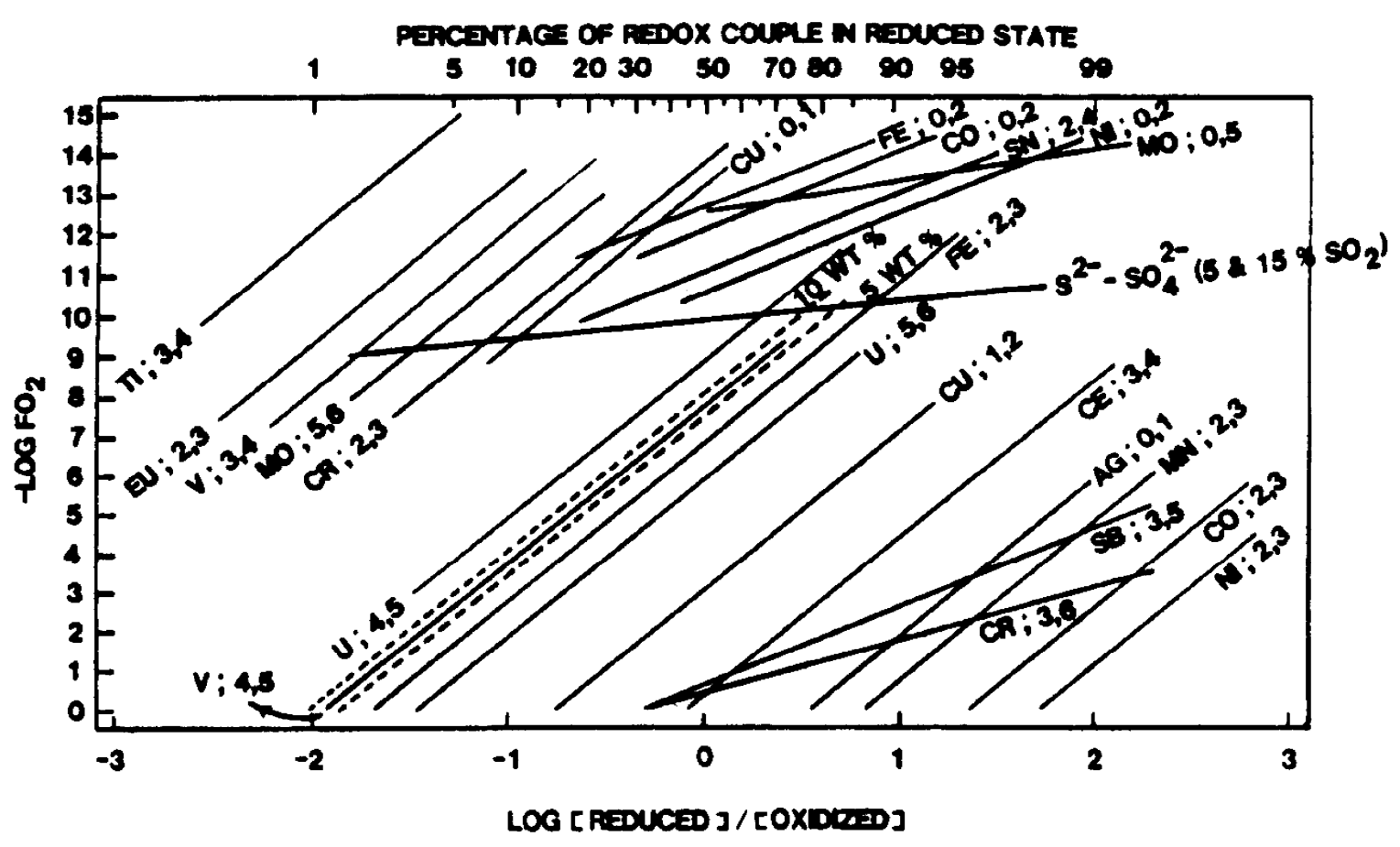

Figure 3. Schreiber's relationship between imposed oxygen fugacity $\left(-\log f\left(\mathrm{O}_{2}\right)\right)$ and the REDOX ratio $(\log ([$ reduced ion $] /[$ oxidized ion $]))$ for multivalent elements doped into SRL- 131 melt at $1150^{\circ} \mathrm{C}$. The broken lines represent 5 and $10 \mathrm{wt} \%$ Fe in SRL-131. This ordering of the REDOX couples in fugacity-REDOX space defines an Electro Motive Force (EMF) series describing the ease of reduction of the ions represented.

\subsection{Volumes of FBSR Product For DWPF}

The 250,000 gallons of T48H slurry should make 29,470 gallons of solid FBSR $\mathrm{Na}_{2} \mathrm{SiO}_{3}$ solid product or $\sim 26,246$ gallons of solid FBSR $\mathrm{Na}_{2} \mathrm{CO}_{3}$ solid product for subsequent treatment in the DWPF. This is an 88 and $90 \%$ volume reduction. This calculation assumes a final FBSR product density of $1.46 \mathrm{~g} / \mathrm{cc}$ which was the number measured for the $\mathrm{Na}_{2} \mathrm{CO}_{3}$ solid FBSR bed product by INEEL [10].

It is recommended that the solid FBSR products, especially the $\mathrm{Na}_{2} \mathrm{CO}_{3}$ product be added to the DWPF sludge waste tank so that the product can be decarbonated via the existing DWPF acid addition strategy for carbonate destruction in the SRAT. This should eliminate any potential for $\mathrm{CO}_{2}$ off-gas surges or foaming in the DWPF melter. It is calculated that 25,500 gallons of steam reforming product (almost all of T48) could be added to the next 500,000 gallon DWPF sludge batch (at $18 \mathrm{wt} \%$ solids). This is based on the substitution of $\sim 7 \mathrm{wt} \% \mathrm{Na}_{2} \mathrm{O}$ from the steam reformer product being substituted for $7 \mathrm{wt} \% \mathrm{Na}_{2} \mathrm{O}$ in a given DWPF frit. This was the same approach taken when the sodium-borate rich Precipitate Hydrolysis Aqueous (PHA) components were substituted for $7 \mathrm{wt} \%$ of the DWPF frit, e.g. instead of adding $72 \mathrm{wt} \%$ frit to $28 \mathrm{wt} \%$ waste, a mixture of $65 \mathrm{wt} \%$ frit plus $7 \mathrm{wt} \%$ PHA was added to $28 \mathrm{wt} \%$ waste [21]. Additional 


\section{WSRC-TR-2003-00352, Rev. 0}

investigation of the $7 \mathrm{wt} \% \mathrm{Na}_{2} \mathrm{O}$ substitution to the next sludge batch would need to be further assessed in the DWPF frit development program.

\subsection{CONCLUSIONS}

The purposes of the current study, organic destruction and downstream processing of $\mathrm{T} 48 \mathrm{H}$ waste slurry, were fulfilled as documented by the following:

- $\quad$ TPB was destroyed in all 19 samples tested with the simulated FBSR process at operational temperatures $650-725^{\circ} \mathrm{C}$

- the $650^{\circ} \mathrm{C}$ operational temperature seemed to optimize the $\mathrm{NO}_{3}$ destruction

- destruction of nitrate at $>99 \%$ was achieved with addition of sugar as a reductant at $1 \mathrm{X}$ stoichometry and TOC analyses indicated that excess reductant was not present in the FBSR product

- destruction of anitfoam with the simulated FBSR process was also achieved at operating temperatures between $650-725^{\circ} \mathrm{C}$ based on measured TOC

- for all tests in which $\mathrm{Na}_{2} \mathrm{CO}_{3}$ was the desired FBSR product phase, $\mathrm{Na}_{2} \mathrm{CO}_{3}$ was produced

- the $\mathrm{Na}_{2} \mathrm{CO}_{3}$ product was shown to be compatible with the DWPF melt process as it melted at $980^{\circ} \mathrm{C}$ as measured by DTA

- for all tests in which $\mathrm{Na}_{4} \mathrm{SiO}_{4}$ or $\mathrm{Na}_{2} \mathrm{SiO}_{3}$ was the desired FBSR product a different sodium silicate formed $\left(\mathrm{Na}_{2} \mathrm{O}: \mathrm{SiO}_{2}\right.$ ratios were not correct)

- this was determined to be a problem with water absorption of the $\mathrm{SiO}_{2}$ additives used and the consumption of $\mathrm{SiO}_{2}$ by a potassium aluminate zeolite (faugesite) that formed

- optimization of the $\mathrm{Na}_{2} \mathrm{O}: \mathrm{SiO}_{2}$ ratio of the feeds still need to be optimized

- formation of a sodium silicate (mixed with $\mathrm{Na}_{2} \mathrm{CO}_{3}$ or alone) is compatible with mixing the FBSR product into a DWPF feed tank or as an addition to the Slurry Mix Evaporator (SME) in place of some of the frit for subsequent vitrification because the mixtures melted at temperatures of $1022^{\circ} \mathrm{C}$ and $1049^{\circ} \mathrm{C}$, respectively, as measured by DTA

- the melt temperature of the $\mathrm{Na}_{2} \mathrm{CO}_{3}$ and $\mathrm{Na}_{2} \mathrm{SiO}_{3} \mathrm{FBSR}$ products $\left(980^{\circ} \mathrm{C}\right.$ and $1022-1049^{\circ} \mathrm{C}$ is low enough to ensure that addition of the FBSR product to the DWPF will not adversely impact melt rate

- the use of sugar at $1 \mathrm{X}$ stoichometry appears to ensure that excess reductant is not contained in the FBSR product that would alter the REDuction/OXidation (REDOX) equilibrium of the DWPF melter while simultaneously assuring that $\mathrm{NO}_{3}$ is destroyed adequately

- the recommended test parameters for pilot scale testing of Tank $48 \mathrm{H}$ simulant at Idaho National Engineering and Environmental Laboratory (INEEL) were given by samples T48-5B for the $\mathrm{Na}_{2} \mathrm{CO}_{3}$ product and by T48-14 for the $\mathrm{Na}_{2} \mathrm{SiO}_{3}$ product 


\section{WSRC-TR-2003-00352, Rev. 0}

- the sealed crucible studies demonstrated that bench scale studies can duplicate the complex reactions, especially the Water Gas Shift Reactions, and the associated $\log p_{\mathrm{H}_{2} \mathrm{O}} / p_{\mathrm{H}_{2}}$ and $\log p_{\mathrm{CO}_{2}} / p_{\mathrm{CO}}$ atmospheres in the FBSR process.

\subsection{RECOMMENDATIONS}

- Re-examine the tests that used less than $1 \mathrm{X}$ stoichiometric sugar (to ensure no carbon residue in the FBSR product going to DWPF) at 48 hours residence time

- Optimize the $\mathrm{SiO}_{2}$ addition strategy to ensure that a $\mathrm{Na}_{2} \mathrm{SiO}_{3}$ silicate product FBSR product is produced

- Revisit the melting temperature of the silicate FBSR products once they are optimized

- Investigate the compatibility of the $\mathrm{Na}_{2} \mathrm{CO}_{3}$ and $\mathrm{Na}_{2} \mathrm{SiO}_{3} \mathrm{FBSR}$ products with DWPF acid addition strategy

- Investigate the frit modifications that would be necessary to accommodate either a $\mathrm{Na}_{2} \mathrm{CO}_{3}$ and $\mathrm{Na}_{2} \mathrm{SiO}_{3}$ FBSR product in DWPF 
WSRC-TR-2003-00352, Rev. 0

APPENDIX A

PHOTOGRAPHIC DOCUMENTATION OF SAMPLE INHOMOGENEITY 
WSRC-TR-2003-00352, Rev. 0

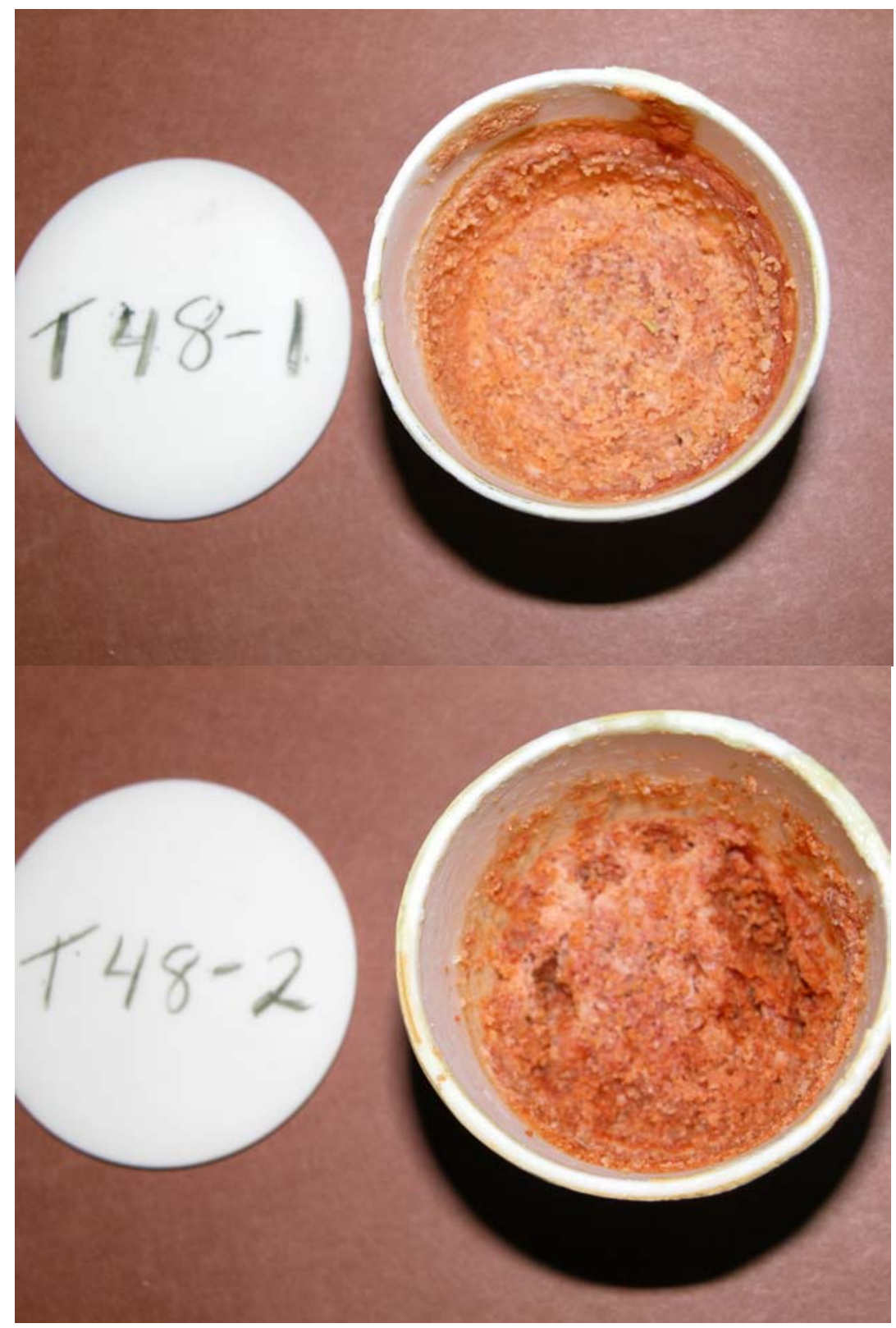


WSRC-TR-2003-00352, Rev. 0

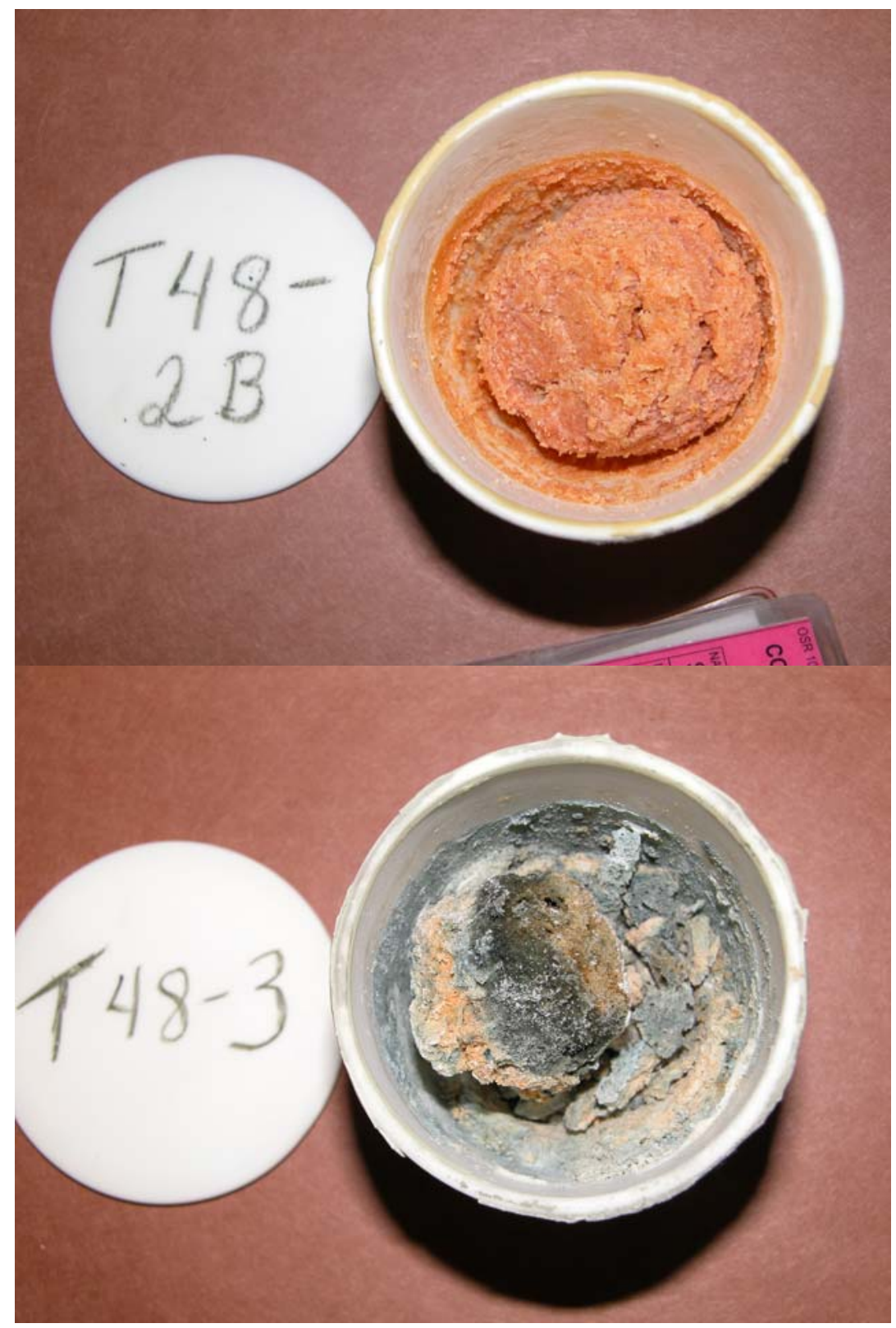


WSRC-TR-2003-00352, Rev. 0

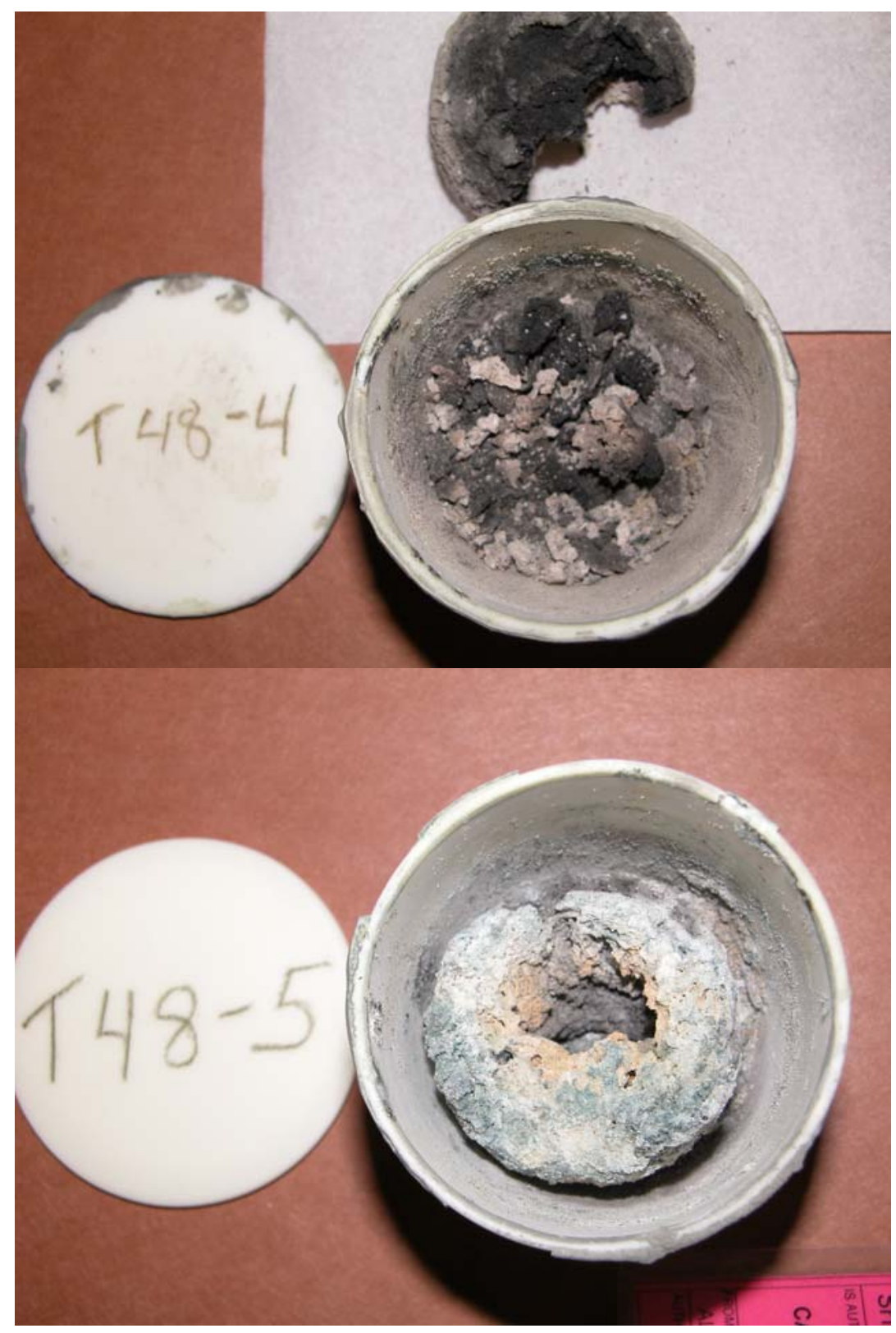


WSRC-TR-2003-00352, Rev. 0

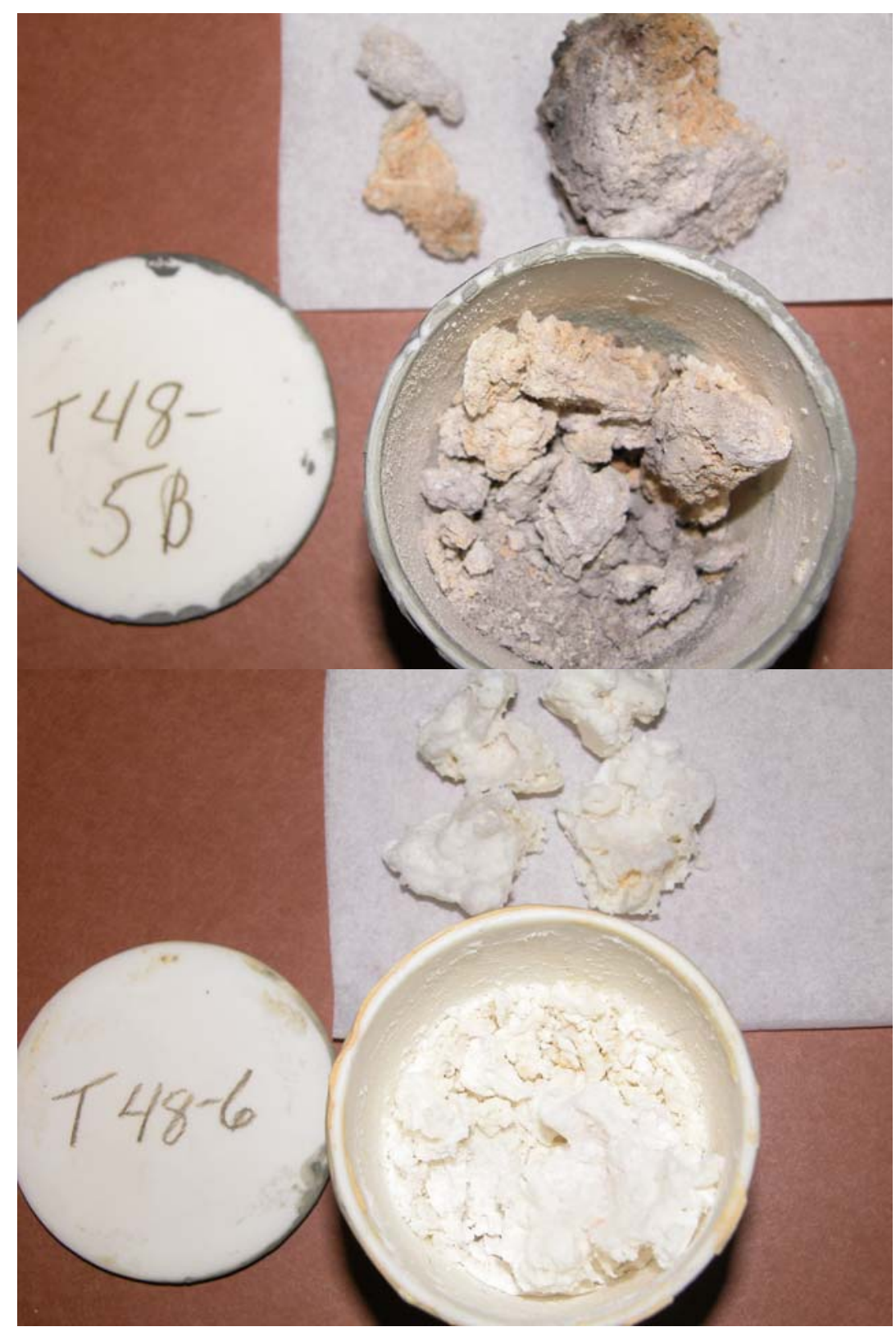


WSRC-TR-2003-00352, Rev. 0

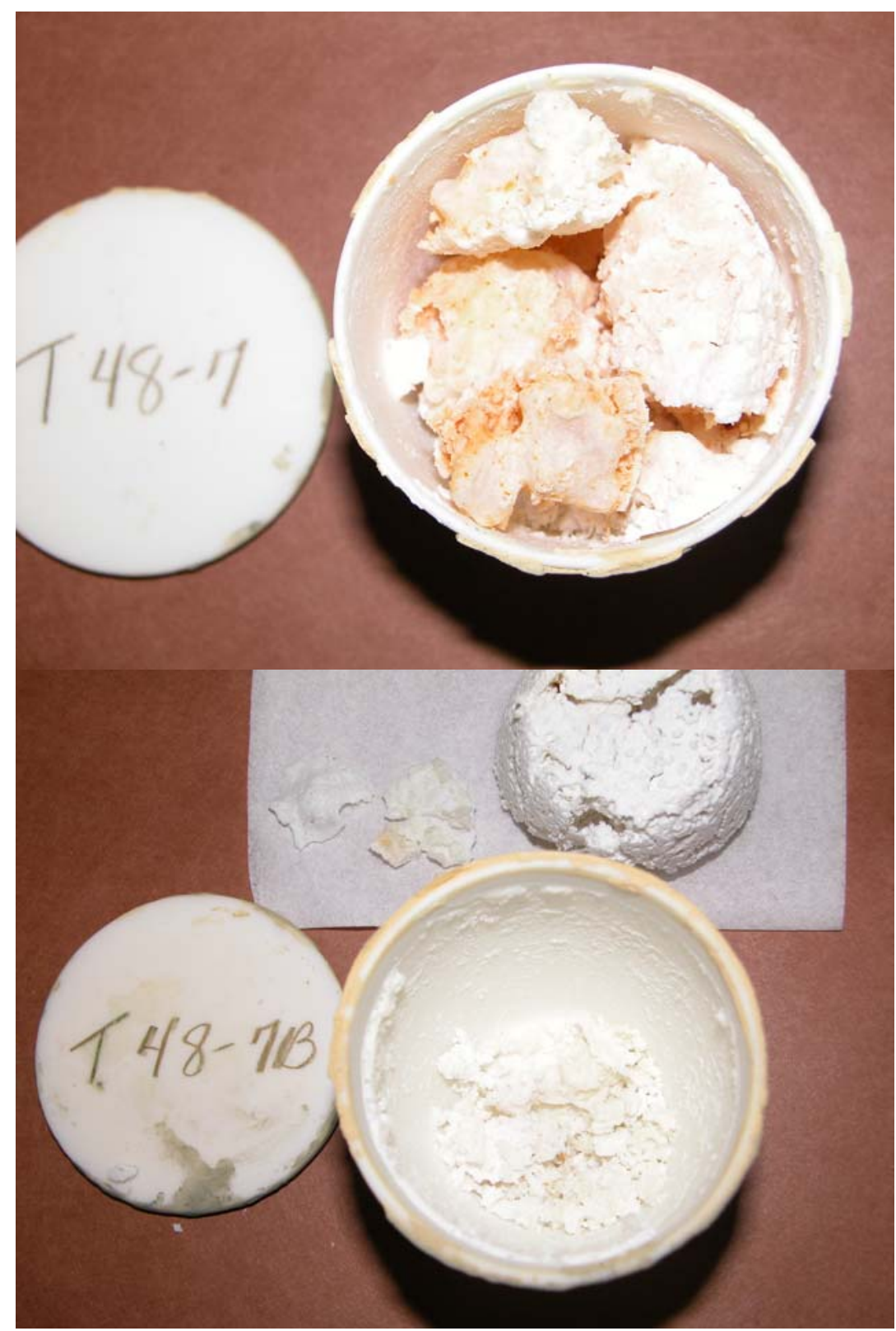


WSRC-TR-2003-00352, Rev. 0

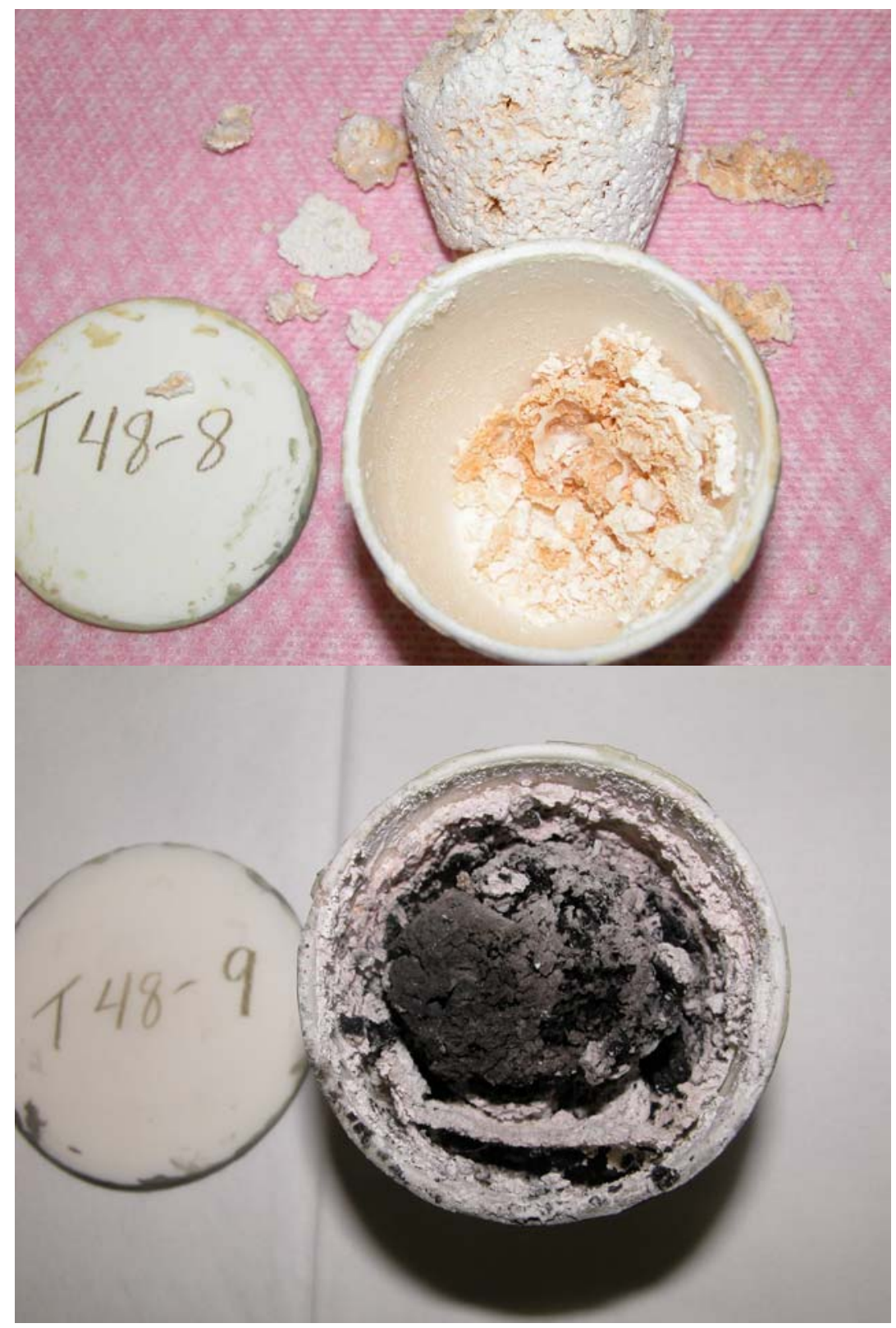


WSRC-TR-2003-00352, Rev. 0

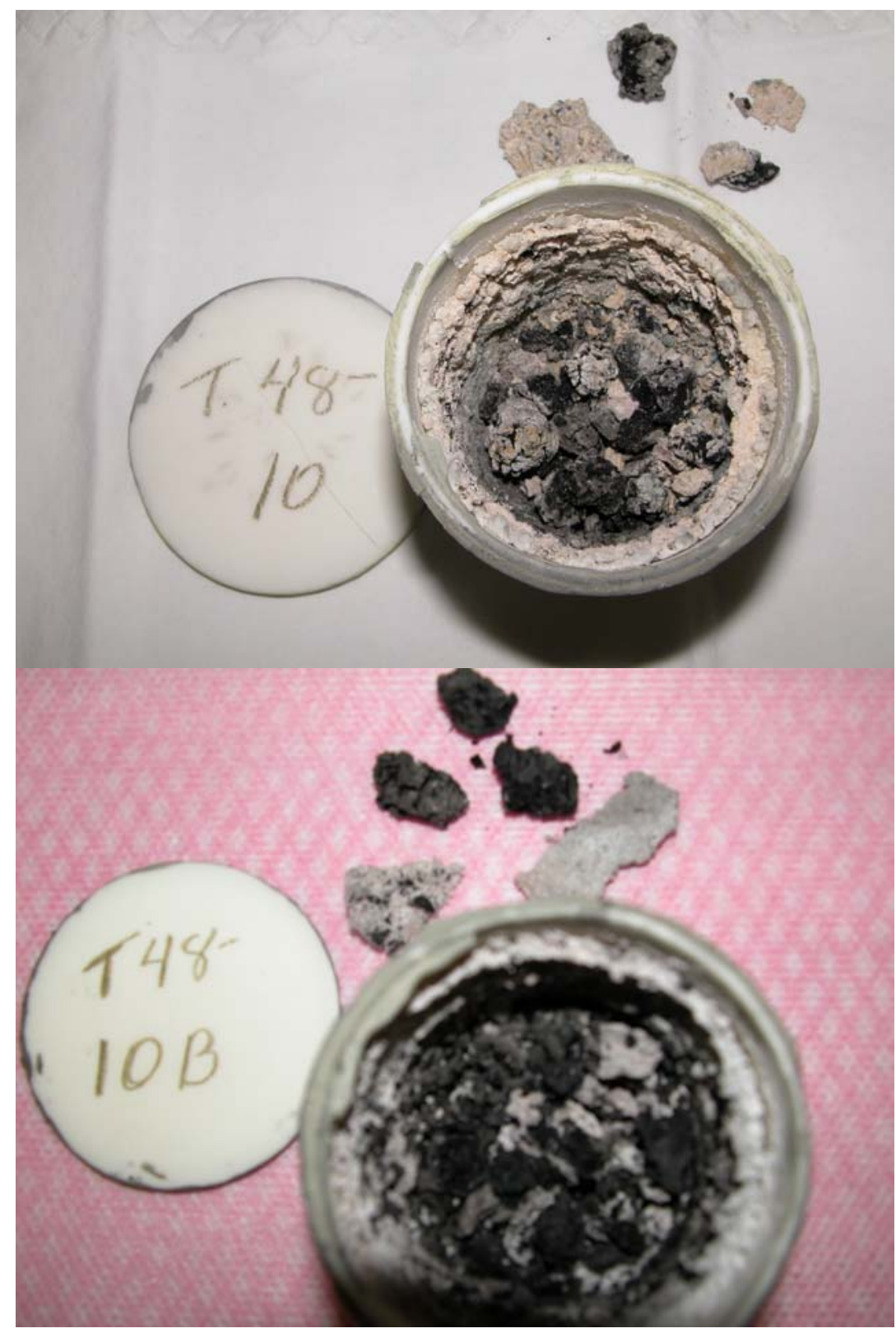


WSRC-TR-2003-00352, Rev. 0

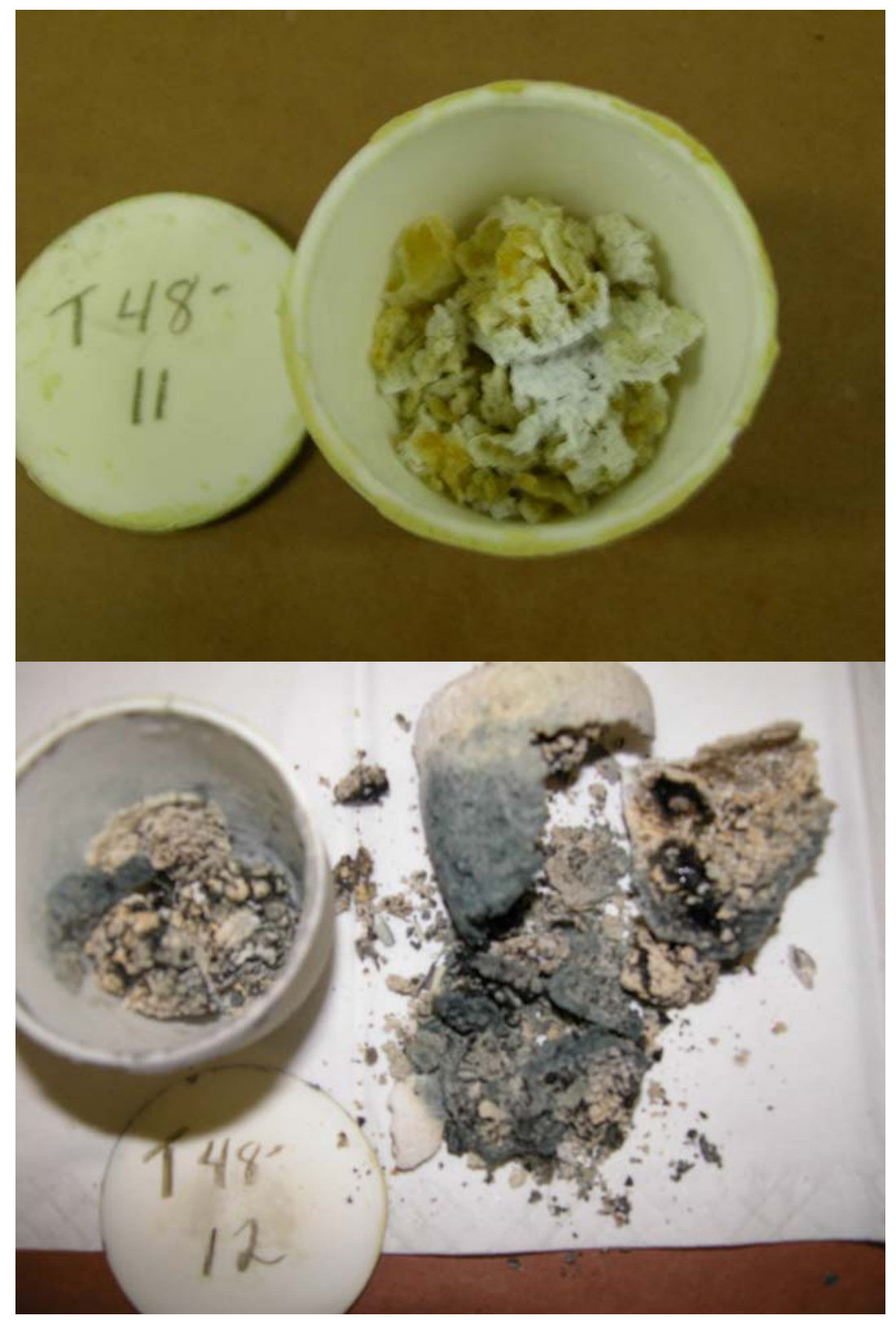


WSRC-TR-2003-00352, Rev. 0

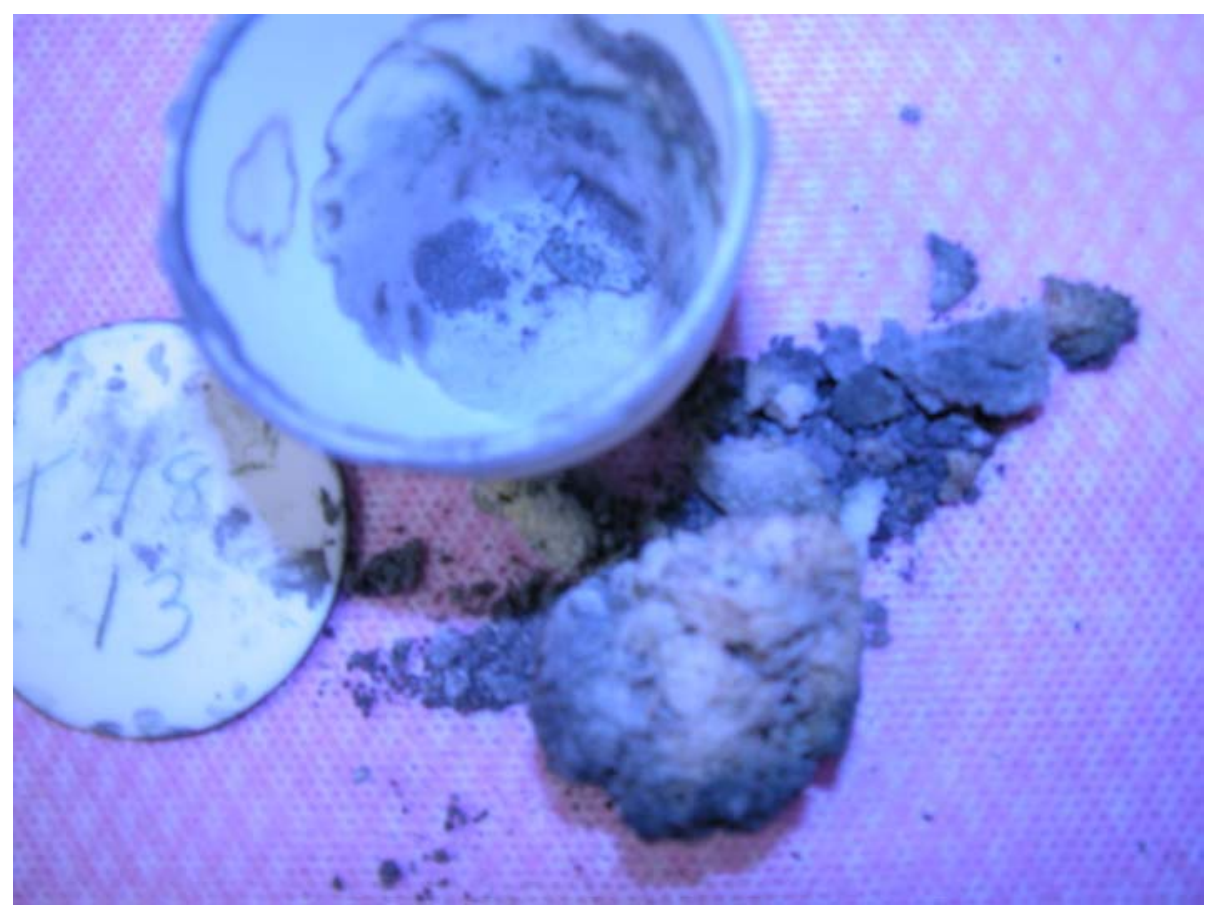


WSRC-TR-2003-00352, Rev. 0

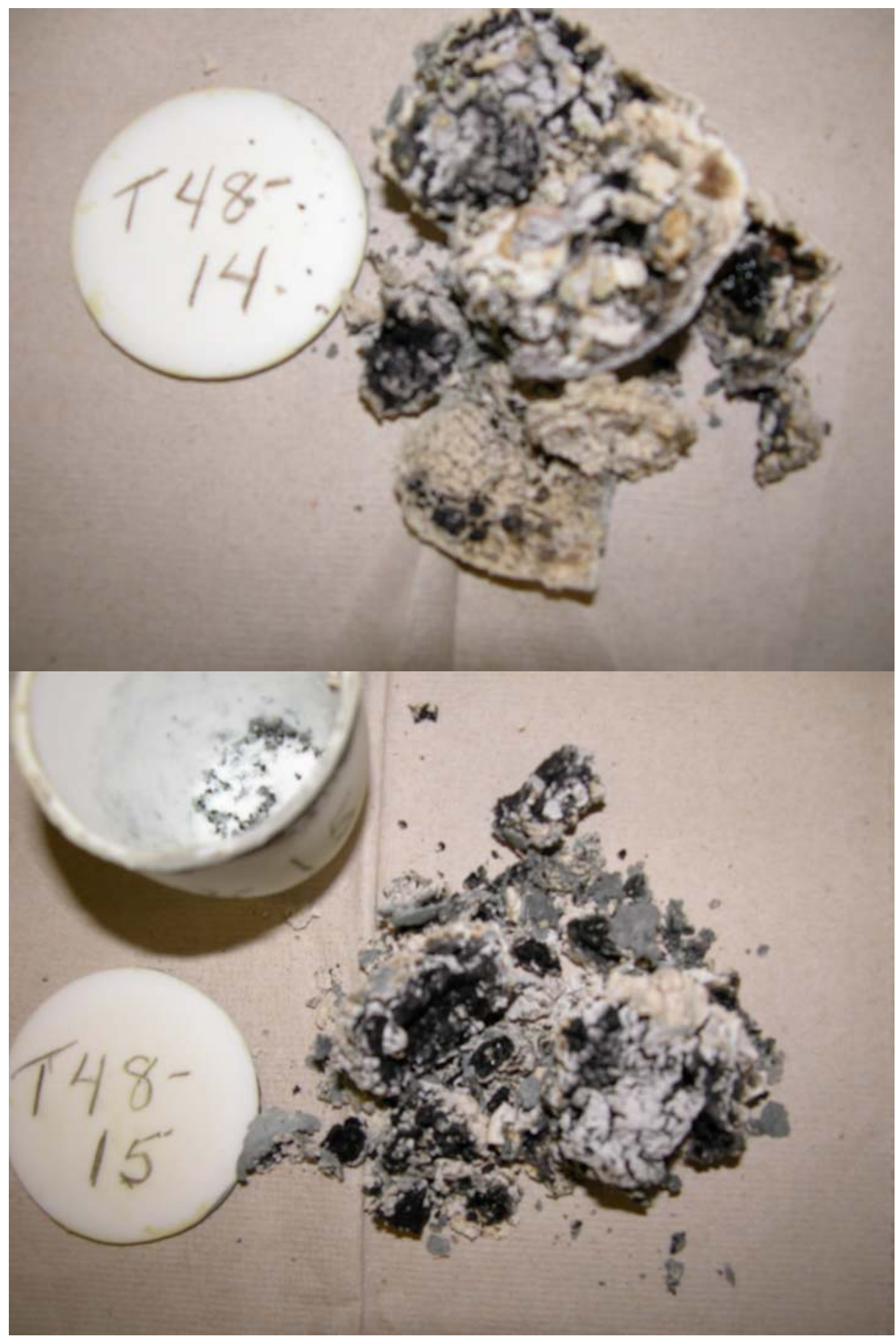


WSRC-TR-2003-00352, Rev. 0

\subsection{REFERENCES}

1 D.D. Walker, M.J. Barnes, C.L. Crawford, R.F. Swingle, R.A. Peterson, M.S. Hay, and S.D. Fink, "Decomposition of Tetraphenylborate in Tank 48H," U.S. DOE Report WSRC-TR-96-0113, Rev. 0, Westinghouse Savannah River Co., Aiken, SC (May 1996).

2 C.M. Jantzen, "Glass Compositions and Frit Formulations Developed for DWPF," U.S. DOE Report DPST-88-952, E.I. duPont deNemours \& Co., Savannah River Laboratory, Aiken, SC (November 15, 1988).

3 S.H. Reboul and D.P. Lambert, "Technical Program Plan for Tank 48H Processing,” CBU-PED-2003-00014, Rev.0 (May 2003).

4 R.A. Adams, et. al. "HLW Tank 48 Disposition Alternatives Identification Phase I and II Summary Report,", U.S. DOE Report, WSRC-RP-2002-00154 Westinghouse Savannah River Co., Aiken, SC (July, 2002).

5 J.B. Mason, J. McKibben, J. Ryan, J. Schmoker, "Steam Reforming Technology for Denitration and Immobilization of DOE Tank Wastes," Waste Management 03 Conference (February 2003).

6 C.M. Jantzen, "Engineering Study of the Hanford Low Activity Waste (LAW) Steam Reforming Process," U.S. DOE Report WSRC-TR-2002-00317, Westinghouse Savannah River Co., Aiken, SC (July 2002).

7 C. M. Jantzen, J. R. Zamecnik, D.C. Koopman, C.C. Herman, and J. B. Pickett, "Electron Equivalents Model for Controlling REDuction-OXidation (REDOX) Equilibrium During High Level Waste (HLW) Vitrification," U.S. DOE Report WSRC-TR-2003-00126 (May 9, 2003).

8 J.B. Mason, T.W. Oliver, M.P. Carson, and G.M. Hill, "Studsvik Processing Facility Pyrolysis/Steam Reforming Technology for Volume and Weight Reduction and Stabilization of LLRW and Mixed Wastes," Waste Management 99 Conference, (February 1999).

9 B.P. McGrail, H.T. Schaef, P.F. Martin, D.H. Bacon, E.A. Rodriguez, D.E. McCready, A.N. Primak, and R.D. Orr, "Initial Evaluation of Steam-Reformed Low Activity Waste for Direct Land Disposal," U.S. DOE Report PNWD-3288, Battelle Pacific Northewest Division, Richland, WA (January 2003).

10 D.W. Marshall, N.R. Soelberg, K.M. Shaber, "THOR ${ }^{\text {sm }}$ Bench-Scale Steam Reforming Demonstration," U.S. DOE Report INEEL/EXT.03-00437, Idaho National Engineering \& Environmental Laboratory, Idaho Falls, ID (May 2003). 
11 N. Soelberg, D. Marshall, S.O. Bates, and D. Siemer, "DRAFT SRS Tank 48 Steam Reforming Proof-of-Concept Test Results," INEEL/EXT-03-01118 (DRAFT August, 2003).

12 M.A. Baich, D.P. Lambert, and P.R. Monson, "Laboratory Scale Antifoam Studies for the STTPB Process," U.S. DOE Report WSRC-TR-2000-00261, Rev.0, Westinghouse Savannah River Co., Aiken, SC (October 24, 2000).

13 E.W. Baumann, "Colorimetric Determination of Iron(II) and Iron(III) in Glass," Analyst, 117, 913-916 (1992).

14 D.R. Best, "Determining $\mathrm{Fe}^{+2} / \mathrm{Fe}^{+3}$ and $\mathrm{Fe}^{+2} / \mathrm{Fetotal}^{\mathrm{U}}$ sing the HP8452A Diode Array Spectrometer," Procedure Manual L28, Procedure 1.8 Rev. 2 (March 14, 2001).

15 E. M. Levin, C.R. Robbins, and H.F. McMurdie, "Phase Diagrams for Ceramists," Vol I, American Ceamic Society, Westerville, OH, Figure 506, 601pp. (1964).

16 E. M. Levin, C.R. Robbins, and H.F. McMurdie, "Phase Diagrams for Ceramists," Vol II, American Ceamic Society, Westerville, OH, Figure 2284, 623pp. (1969).

17 C.M. Jantzen, "Vitrification of Melter Slurries for Glass REDOX (Fe+2/SFe) and Chemical Composition Measurement," Procedure ITS-0052, Rev.0, Savannah River Technology Center Immobilzation Technology Section Procedure Manual L29, Revision 3 (August 22, 2002).

18 T.B. Peters, D.P. Lambert, M.E. Smith, and S.D. Fink, "Task Technical and Quality Assurance Plan for Destruction of Tetraphenylborate in Tank 48H," U.S. DOE Report WSRC-RP-2003-00396, Westinghouse Savannah River Company, Aiken, SC (May 2003).

19 H.D. Schreiber, and A.L. Hockman, "Redox Chemistry in Candidate Glasses for Nuclear Waste Immobilization," Journal of the American Ceramic Society, Vol. 70, No. 8, pp. 591-594 (1987).

20 A. Muan and E.F. Osborn, "Phase Equilibria Among Oxides in Steelmaking," Addison-Wesley Publ. Co., Reading, MA, 236pp (1965).

21 C.M. Jantzen, "Glass Compositions and Frit Formulations Developed for DWPF," U.S. DOE Report DPST-88-952, E.I. duPont deNemours \& Co., Savannah River Laboratory, Aiken, SC (November 15, 1988). 